Portland State University

PDXScholar

Summer 1-1-2012

\title{
Streamflow Analysis and a Comparison of Hydrologic Metrics in Urban Streams
}

Matthew Lawton Wood

Portland State University

Follow this and additional works at: https://pdxscholar.library.pdx.edu/open_access_etds

Part of the Nature and Society Relations Commons, Physical and Environmental Geography Commons, and the Urban Studies and Planning Commons Let us know how access to this document benefits you.

\section{Recommended Citation}

Wood, Matthew Lawton, "Streamflow Analysis and a Comparison of Hydrologic Metrics in Urban Streams" (2012). Dissertations and Theses. Paper 769.

https://doi.org/10.15760/etd.769

This Thesis is brought to you for free and open access. It has been accepted for inclusion in Dissertations and Theses by an authorized administrator of PDXScholar. Please contact us if we can make this document more accessible: pdxscholar@pdx.edu. 
Streamflow Analysis and a Comparison of Hydrologic Metrics in Urban Streams

\title{
by
}

Matthew Lawton Wood

A thesis submitted in partial fulfillment of the requirements for the degree of

\author{
Master of Science \\ in \\ Geography
}

\section{Thesis Committee: \\ Heejun Chang, Chair \\ Martin Lafrenz \\ Joseph Poracsky}

Portland State University

(C)2012 


\begin{abstract}
This study investigates the hydrologic effects of urbanization in two Portland, Oregon streams through a comparison of three hydrologic metrics. Hydrologic metrics used in this study are the mean annual runoff ratio $\left(Q_{a}\right)$, mean seasonal runoff ratio $\left(Q_{w}\right.$ and $\mathrm{Q}_{\mathrm{d}}$ ), and the fraction of time that streamflow exceeds the mean streamflow during the year (TQmean). Additionally, the relative change in streamflow in response to storm events was examined for two watersheds. For this investigation urban development is represented by two urbanization metrics: percent impervious and road density. Descriptive and inferential statistics were used to evaluate the relationship between the hydrologic metrics and the amount of urban development in each watershed. The effect of watershed size was also investigated using nested watersheds, with watershed size ranging from $6 \mathrm{~km}^{2}$ to $138 \mathrm{~km}^{2}$. The results indicate that annual and seasonal runoff ratios have difficulty capturing the dynamic hydrologic behavior in urban watersheds. TQmean was useful at capturing the flashy behavior of the Upper Fanno watershed, however it did not perform as well in Kelley watershed possibly due to the influence of impermeable soils and steep slopes. Unexpected values for hydrologic metrics in Lower Johnson, Sycamore and Kelley watersheds could be the result water collection systems that appear to route surface water outside of their watersheds as well as permeable soils. Storm event analysis was effective at characterizing the behavior for the selected watersheds, indicating that shorter time scales may best capture the dynamic behavior of urban watersheds.
\end{abstract}




\section{Acknowledgements}

I would like express my gratitude to all of those who without this thesis would not have been possible. I would like to acknowledge the indispensible advice and guidance of my advisor Dr. Heejun Chang. I also thank the members of my committee, Joseph Poracsky and Martin Lafrenz for their guidance and suggestions. I am grateful to Il-won Jung for his technical expertise assisting with data manipulation. I would like to thank my fiancée Gabriela for her endless support and encouragement throughout this process. Lastly, thanks to my family who have always encouraged me to pursue my interests and dreams. 


\section{Table of Contents}

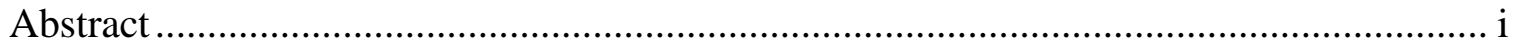

Acknowledgements ............................................................................................... ii

List of Tables ........................................................................................................... iv

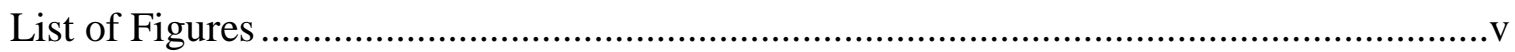

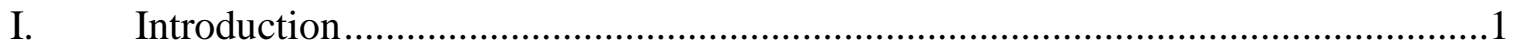

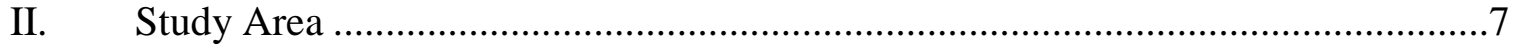

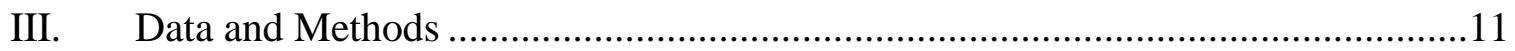

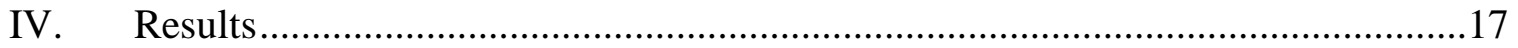

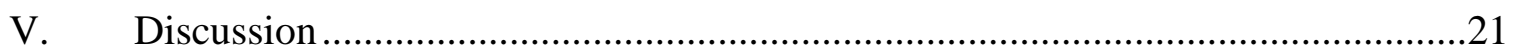

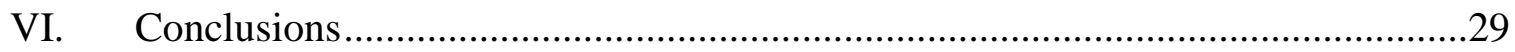

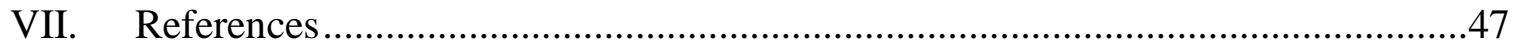




\section{List of Tables}

Table 1. Data types and sources used for the study .................................................32

Table 2. USGS monitoring stations and hydrologic characteristics ..............................33

Table 3. Length of hydrological record for USGS stations ........................................34

Table 4. Weather stations used for precipitation records...........................................34

Table 5. Urban development in each watershed represented by road density and percent

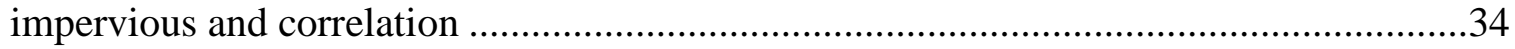

Table 6. Kruskall-Wallis test for testing independence of hydrologic metrics among

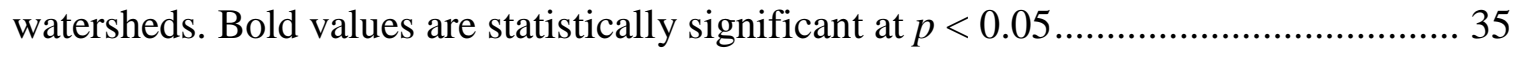

Table 7. Mean annual runoff ratios $\left(\mathrm{Q}_{\mathrm{a}}\right)$ for each watershed .......................................35

Table 8. Kendall's tau rank correlation values between hydrologic metrics and urbanization metrics. Bold values are statistically significant at $p<0.05$.

Table 9. Trend analysis for each hydrologic metric for the Sycamore watershed. Bold values are significant at $p<0.05$

Table 10. Mann-Whitney test values comparing $\mathrm{Q}_{\mathrm{w}}$ and $\mathrm{Q}_{\mathrm{d}}$ to evaluate seasonal differences. Bold values are statistically significant at $p<0.05$.

Table 11. Differences in seasonal runoff ratio in comparison to levels of urbanization ...36

Table 12. Kendall's tau rank correlation values between hydrologic metrics and watershed size. Bold values are statistically significant at $p<0.05$

Table 13. Watershed areas for topographic and piped drainage watershed delineations ..37 


\section{List of Figures}

Figure 1. Map of Fanno and Johnson Creek watersheds study area and subwatersheds...38

Figure 2. Relationship between elevation and annual mean precipitation for Johnson Creek Hydra rain gages used to adjust Portland International Airport NWS Station.........38

Figure 3. Map of Fanno and Johnson Creek "piped drainage watershed” delineated using both the topology and stormwater sewer network

Figure 4. Distribution of mean annual runoff ratios (Q $\left.\mathrm{Q}_{\mathrm{a}}\right)$ for 2001-2011

Figure 5. Relationship between mean annual runoff ratio $\left(\mathrm{Q}_{\mathrm{a}}\right)$ and percent impervious...40

Figure 6. Relationship between mean annual runoff ratio $\left(\mathrm{Q}_{\mathrm{a}}\right)$ and road density....

Figure 7. Distribution of mean seasonal runoff ratios $\left(\mathrm{Q}_{\mathrm{w}}\right.$, Wet Season and $\mathrm{Q}_{\mathrm{d}}$, Dry Season) for 2001-2011

Figure 8. Relationship between road density and the wet season runoff ratio $\left(Q_{w}\right)$

Figure 9. Relationship between percent impervious and the wet season runoff ratio $\left(\mathrm{Q}_{\mathrm{w}}\right)$

Figure 10. Distribution of fraction of time that daily mean flow exceeds annual mean

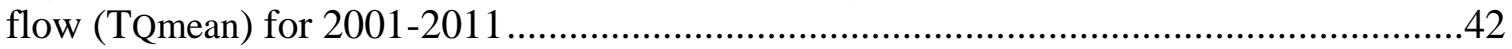

Figure 11. Relationship between TQmean and road density .......................................43

Figure 12. Relationship between TQmean and percent impervious ................................43

Figure 13. Effects of precipitation on changes in streamflow for Lower Fanno watershed

Figure 14. Effects of precipitation on changes in streamflow for the Lower Johnson watershed

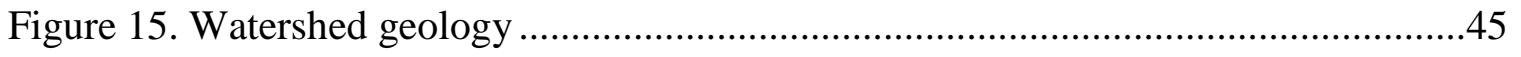

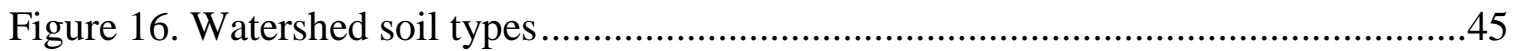

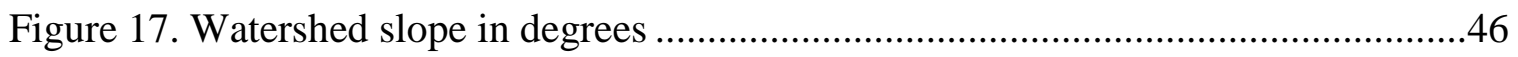

Figure 18. Relationship between USGS gage elevation and mean annual runoff ratio $\left(\mathrm{Q}_{\mathrm{a}}\right)$ 


\section{Introduction}

With more than $80 \%$ of the U.S. population and nearly half of the world's population living in urban areas in 2007, urbanization of landscapes is pervasive and growing rapidly (United Nations 2008). National comparisons display that the state of Oregon has experienced above average population growth, with an annual average rate of $1.2 \%$ from 2000 to 2006 . Much of the growth has been within urban areas, with $78 \%$ of Oregon’s population residing in one of six metropolitan statistical areas (Oregon Population Report 2009). Oregon’s largest city, Portland, has experienced rapid population growth reflected by a 19\% increase from 1980 to 1990, a 21\% increase from 1990 to 2000 and a 10.3\% increase from 2000 to 2010 (US Census Bureau 2012). As populations continue to grow, conversion of land from rural to urban will continue and urbanization will place pressure upon regional water resources (United Nations 2008).

Urbanization is a global phenomenon that is dramatically altering the natural hydrologic processes and is directly and indirectly impairing the health of the world's water systems. The conversion of permeable surfaces into impervious urban structures is accompanied by the following major changes in nearby streams: increased contribution and decreased transport time of surface runoff; reduced lag time between precipitation event and peak flow event; a decreased contribution of precipitation into the groundwater system; increased peak flows and decreased low flows.

Urban development alters the hydrologic cycle by removing vegetation and replacing pervious land with impervious surfaces such as buildings and roads. Impervious surfaces associated with urban development prevent the infiltration of rainfall into groundwater systems, and instead leads to increased surface runoff. Stormwater drainage 
systems associated with urban development further alter the natural hydrologic cycle by routing surface runoff into underground drainage pipes and into nearby streams. These changes result in faster conveyance of precipitation events into streams, and the effects have been well documented. The objectives of this study are to investigate the performance of hydrologic metrics utilized to characterize the behavior of urban streams.

Changes in land use and land cover have been shown to directly affect a system's water yield by altering the hydrologic cycle (Chang 2007). The principal effects of urban development are changes in peak flow characteristics, total runoff volume, and water quality (Leopold 1968; Hammer 1972; Paul and Meyer 2001). The modification of land surface during urban development exposes soil to storm runoff, yielding high sediment loads in streams (Leopold 1968). Increased imperviousness has been associated with increases in urban runoff, evapotranspiration, and nonpoint source pollution (Bhaduri et al. 2001). Increases in urban runoff have been shown to increase the frequency and magnitude of flood events (Booth and Jackson 1997).

A variety of physical characteristics determine watershed response to precipitation events. Watershed land use and land cover have been widely used as predictors of stream behavior and health. In addition to climate patterns, soil type, land cover, and elevation, the amount of impervious surface has emerged as a useful indicator of land development and its effect on watershed health (Schueler 1994; Arnold and Gibbons 1996). The use of impervious cover as a predictor of watershed and stream health has demonstrated the effects of urban areas on surface runoff (Horner et al. 1997), baseflow (Kauffman et al. 2009), streamflow (Hollis 1975; Jennings and Jarnagin 2002), 
channel incision (Leopold 1956; Hardison et al. 2009), water quality (May et al. 1997), and aquatic habitat and life (Finkenbine et al. 2000; Ourso and Frenzel 2003).

Arnold and Gibbons (1996) cited the usefulness of imperviousness as an environmental indicator due to two factors. First, imperviousness is integrative in its ability to predict cumulative water resource impacts without regard to specific factors (e.g. water quality, hydrology, biotic integrity). Second, it is measurable in that there are a variety of techniques used to measure imperviousness. Importantly, impervious cover is not measured or characterized in the same way by all researchers. Common methods include total impervious area (TIA), percent impervious, effective impervious area (EIA), curve numbers (CN) and urban intensity indices (e.g. road density).

A great deal of research has investigated the link between the presence of impervious cover with changes in stream health and behavior. Cianfrani et al. (2006) surveyed forty-six independent stream reaches in south eastern Pennsylvania and using multivariate statistical analysis found a significant relationship, linking higher TIA values with reduced large woody debris and channel sinuosity. Finkenbine et al. (2000) found that increases in TIA were correlated with a decrease in summer baseflow, and a decrease of instream cover available for aquatic life. Schiff and Benoit (2007) used a multiparameter water quality index in a New Haven, Connecticut watershed and found a critical level of 5\% TIA, above which stream quality declined. Research conducted in the Pacific Northwest however, has suggested a threshold for urban stream health at $10 \%$ imperviousness (Booth 1991).

In an evaluation of urban streamflow patterns in the Puget Lowland of Washington, Konrad et al. (2005) utilized both \%TIA and road density to represent the 
level of urban development within their study area. Their investigation found road density was significantly correlated with reference high flow events and not reference flows based on cumulative runoff volume or the duration of the flow. This correlation indicates that urban development increases the frequency of high flows but not their cumulative duration. It has been shown that cumulative streamflow volume, often represented by mean streamflow rate Qmean, does not always change in response to urbanization (Rose and Peters 2001; Konrad and Booth 2002; Konrad et al. 2005).

In the same study Konrad et al. (2005) used three hydrologic metrics to investigate the influence of urban development on stream channel form and streambed stability. The hydrologic metrics they selected, fraction of time streamflow exceeds mean streamflow (TQmean), the coefficient of variation of annual maximum streamflow $\left(\mathrm{CV}_{\mathrm{AMF}}\right)$, and the fraction of time streamflow exceeds the 0.5-year flood $\left(\mathrm{T}_{0.5}\right)$, integrated the "storm-scale effects" of urban development on annual to decadal scale. TQmean was shown to significantly decline in two creeks where extensive urban development had occurred in the watershed, and displayed weaker relationships in other creeks which had much lower rates of urbanization.

DeGasperi et al. (2009) investigated the relationship between fifteen hydrologic metrics, urban land cover, and the Benthic Index of Biological Integrity (B-IBI) in the Puget Lowland, Washington. Eight hydrologic metrics were significantly correlated with B-IBI scores and all but two hydrologic metrics were significantly correlated with the urbanization metrics, TIA and urban land cover. Their results suggest that the biological integrity of streams is significantly impacted by the hydrology of urbanized watersheds. 
Interestingly, TQmean was one of the two hydrologic metrics that was not significantly correlated with the measures of urbanization.

Streamflow characteristics of watersheds with varying levels of urbanization were evaluated by Rose and Peters (2001) in the Atlanta, Georgia area. Their evaluation of streamflow using various hydrologic metrics found that the most urbanized watershed displayed peak flows 30 to $100 \%$ greater and low-flows 25 to $35 \%$ less than those in less urbanized streams. These results are consistent with the effects of urbanization as impervious surfaces reduce hydraulic transport time creating faster and greater peak flows, and preventing infiltration of precipitation into the groundwater, thereby reducing groundwater contributions to low flows.

While the impact of the urban built environment on hydrologic systems has been widely researched, each system is uniquely influenced by its climate, soils, geology, impervious surfaces, and provides the opportunity to apply hydrologic analysis techniques in new ways. This research utilizes documented techniques including, hydrologic metrics, urbanization metrics and storm event analysis, and applies them a variety of nested scales. The use of nested scales in watershed analysis has been suggested as one way to detect hydrologic impacts of urbanization (Jones 1997), but has not been utilized within Johnson and Fanno Creek watersheds. The large amount of hydrologic data in each watershed provides the opportunity to reveal new insights regarding each system.

This research presents a comparison of hydrologic metrics that seek to quantify the effects of urban development. A comparison of these metrics among watersheds with various levels of development will demonstrate the relationship between increased 
development and hydrologic response. Comparison of two urbanization metrics will also demonstrate any difference in quantifying the amount of development within a watershed and its effect upon surface hydrology. Additionally, the use of watersheds varying in size, as well as a nested watershed approach, will examine any relationship between watershed size and metric performance.

The purposes of this study are to: 1) Evaluate the hydrologic response to urbanization in two streams by use of hydrologic metrics, 2) Evaluate any correlation between the hydrologic metrics and urbanization metrics for each watershed 3) Compare hydrologic metrics at different spatial sizes using nested subwatersheds. 


\section{Study Area}

The City of Portland is the largest city in the state of Oregon with an estimated population of 583,776, incorporated in three counties (US Census Bureau, 2010). Portland experienced significant growth through much of the 1980s and 1990s, and while population growth has slowed within the city, the neighboring suburbs of Hillsboro and Beaverton continue to experience rapid population growth (US Census Bureau 2009). Due to the pressures of population growth, surrounding rural areas will increasingly be under the pressures of urban development. As urban development continues, more pervious green spaces will be converted to impervious surfaces and impact the surrounding hydrologic regime.

This research will focus on two watersheds, Fanno and Johnson Creek, located within the Portland metropolitan area of Oregon. These watersheds were chosen because both have been impacted by urbanization, but they differ in their land use and drainage basin characteristics. Additionally, there is a large amount of hydrological data available from multiple stations within each watershed allowing for different size drainage areas to be evaluated. Johnson Creek flows $41 \mathrm{~km}$ from its head waters in Boring, Oregon, through Clackamas and Multnomah Counties to its confluence with the Willamette River in Milwaukie, Oregon. The upper reaches of Johnson Creek flow west from agricultural lands, through residential and commercial/industrial areas of Gresham and Portland. The lower reach of the creek is highly urbanized and surrounded by dense residential and commercial/industrial areas.

Crystal Springs, Sunshine Creek, Butler Creek, Hogan Creek, Badger Creek, and Kelley Creek are the major tributaries that contribute streamflow to Johnson Creek. 
Crystal Springs is a series of springs that discharge into the Crystal Springs Creek flowing 4km west from Reed College then south through Westmoreland Park and finally feeding into Johnson Creek. There are numerous other small tributaries which also feed into Johnson Creek, most of which are located south of the creek. Kelley Creek is a $7 \mathrm{~km}$ long tributary of Johnson Creek located just east of Portland that has primarily consisted of forest and agriculture, but in recent years has witnessed increased urban land development. The 2002 inclusion of Kelley Creek within the Portland metropolitan urban growth boundary (UGB) is sure to facilitate housing and commercial growth (Metro 2012). The Kelley Creek watershed provides an excellent opportunity to evaluate pre-urbanization hydrologic conditions. Previous research has shown that Kelly Creek is sensitive to altered discharge patterns that accompany increases in impervious surfaces and preserving headwater forests could protect it from disruption (Levell and Chang 2008; Murphy 2009).

Fanno Creek is a $24 \mathrm{~km}$ tributary of the Tualatin River that flows south from its headwaters near the Tualatin Hills in southwest Portland through the cities of Beaverton, Tigard and Durham. The $80 \mathrm{~km}^{2}$ Fanno Creek watershed is highly urbanized and has seen most of its land converted to buildings, roads, streets and other impervious surfaces. The watershed contains steep slopes in areas and consists of primarily silt loam soils. There are a number of smaller tributaries that drain in to Fanno Creek, including Woods Creek, Ash Creek and Vermont Creek.

Differences in the amount of urbanization and physical characteristics such as watershed slope and soil characteristics, result in different hydrological processes and provide an opportunity for investigation. Selection of the watersheds for this study was 
based on the following criteria: at least a ten-year period of recorded hourly streamflow; at least ten-years of hourly precipitation data from a nearby weather station; and no ponds, diversions or dams that would significantly alter the streamflow. Johnson and Fanno Creeks met those criteria, serving as ideal cases for this investigation.

For the purpose of this investigation the Johnson and Fanno Creek watersheds have been further divided into subwatersheds based on the location of US Geological Survey (USGS) streamflow gages. The USGS gages provide long term records of historical streamflow, and their locations were used to define the delineation of Johnson and Fanno Creek subwatersheds. Each subwatershed does not necessarily represent a separate discrete area of the Johnson Creek watershed, but instead watersheds are 'nested' within each other (Figure 1). This approach serves the purpose to evaluate the effect of watershed size on the hydrologic metrics and any correlation with levels of urban development.

Within Johnson Creek watershed, the upper most subwatershed is defined by the USGS station “Johnson Creek at Regner Road” and drains $39.8 \mathrm{~km}^{2}$ of agricultural and rural lands. Soils in the "Regner watershed" consist primarily of silt loam and silty clay loam. The USGS station "Kelley Creek at $159^{\text {th }}$ Drive" was used to define the "Kelley watershed” and drains $12.1 \mathrm{~km}^{2}$ of forested, rural and residential lands that consist primarily of silt loam. The USGS station "Johnson Creek at Sycamore Road” was used to define the "Sycamore watershed" which has both Kelley and Regner subwatersheds nested within, and drains $69.4 \mathrm{~km}^{2}$ of silt loams and silty clay loams. The USGS station “Johnson Creek at Milwaukie” located just upstream from the mouth of Johnson Creek was used to define the "Lower Johnson watershed" which drains $138 \mathrm{~km}^{2}$ of land. Soils 
within the Lower Johnson watershed consist primarily of silt loams and urban complex soils that have been mixed, manipulated and disturbed.

The Fanno Creek watershed contains two USGS stations with long term hydrological records, resulting in one nested watershed in the upper reach. The USGS station "Fanno at $56^{\text {th }}$ Avenue" was used to delineate the "Upper Fanno watershed", and drains $6.1 \mathrm{~km}^{2}$ of highly developed land and as a result consists almost entirely of urban complex soils. The USGS station "Fanno at Durham Avenue" was used to delineate the “Lower Fanno watershed” and drains 80.6 km² of silt loam and urban complex soils.

The City of Portland operates and maintains the combined sewer system (CSS), municipal stormwater sewer system and underground injection control (UIC) systems within the urban areas of Portland. The CSS collects both sewage and stormwater runoff in a single pipe for $33 \mathrm{~km}^{2}$ east of the Willamette, much of which falls in the Lower Johnson watershed (City of Portland, 2010). The stormwater sewer system drains $63 \mathrm{~km}^{2}$ of land for the entire Portland region. As of 2008, it was estimated that there are 11,000 publicly owned UICs and 25,000 to 35,000 privately owned UICs in the Portland metropolitan area (Snyder 2008). The City of Portland's stormwater management infrastructure alters the natural drainage characteristics of both Fanno and Johnson Creek watersheds and while they are not directly included in this study, their role and impact is considered while interpreting the results of this analysis. 


\section{Data and Methods}

\subsection{Data}

Daily streamflow data from U.S. Geological Survey (USGS) monitoring stations was acquired for each watershed (Table 1). Six USGS streamflow monitoring stations, four in Johnson Creek and two in Fanno Creek, were used for daily streamflow data and their locations were used to delineate subwatersheds (Table 2). The USGS stations have different lengths of hydrological records with Johnson at Sycamore having the longest record of 70 years and Kelley the shortest record of 10 years (Table 3). The long term records available for the Sycamore station allow for temporal analysis to be conducted in this study.

Daily precipitation data was acquired from the City of Portland Hydra Rainfall Network and the National Weather Service (Table 1). The Hydra Rainfall Network consists of 36 rain gages within the Portland metropolitan area and has collected hourly rainfall data at stations beginning in 1998. Hydra stations that were closest to USGS stations and provided complete historical records were used for this study. Six Hydra rain gages, four in Johnson Creek and two in Fanno Creek, provided daily precipitation data (Table 4). For precipitation records prior to available Hydra records, historical precipitation data was obtained from NWS stations in Hillsboro and at the Portland International Airport (Table 4). The Hillsboro NWS station was for the Lower and Upper Fanno watersheds, while the Portland International Airport (PDX) NWS Station was used for the Lower Johnson, Sycamore, Kelley and Regner watersheds.

The data used for percent impervious was acquired from the USGS Seamless Data Warehouse. The 2006 National Land Cover Database (NLCD) Impervious Surface 
dataset for the conterminous United States is a 30-meter resolution raster file representing the percent impervious on the ground. Each 30 x 30 raster cell has a unique value ranging from 0-100 representing the percentage of impervious cover. The impervious raster file was clipped using the boundaries of each watershed in the study. The resulting raster files were used to obtain an average value that represented the percent of impervious cover for each watershed.

A 10-meter Digital Elevation Model (DEM) from the USGS National Elevation Dataset was acquired for watershed delineation. Previously delineated watershed boundaries that incorporated the influence of the Metro area's stormwater drainage network were also acquired for anecdotal comparisons with topographic delineations.

Due to the increased distance of NWS stations from Hydra stations some differences in historical precipitation data were observed. A correlation between increasing elevation and precipitation was determined between Hydra stations used for Johnson Creek subwatersheds, and based upon this relationship, PDX records were adjusted accordingly (Figure 2). To ensure better accuracy and to reduce any possible effect of elevation changes, selection of Hydra stations was based on the closest proximity to the USGS monitoring stations used in this study. In the case of missing precipitation records, the missing values were corrected with the missing values from the nearest complete Hydra station data. Missing data were directly supplemented and no interpolation method was used as very few values were missing from historical records.

\subsection{GIS analysis}

A 10-meter Digital Elevation Model (DEM) was used in ArcGIS to create the watersheds using each aforementioned USGS station location. The coordinates of these 
stations were input into ArcGIS and used as "pour points" to delineate the watershed boundaries. The nested watersheds produced by this method are useful for evaluating the effect of watershed size upon different hydrologic metrics and their correlation with different levels of urban development. A GIS watershed dataset that accounted for stormwater drainage was acquired through work in the Portland State Geography Department. Using stormwater drainage networks from Clean Water Services and the City of Portland Bureau of Environmental Services, in conjunction with a 1-m DEM, a “piped drainage watershed” was created for the Portland Metro region. USGS station locations were then used to delineate the six watersheds used in this study (Figure 3).

Two metrics for quantifying urbanization are utilized in this investigation; percent impervious, and road density. Creation of both urbanization metrics required data manipulation in ArcGIS. The impervious surface data obtained from the NLCD required re-projection, clipping to study watersheds, and averaging of raster cells to obtain percent impervious values for each watershed. Road density $\left(\mathrm{km} / \mathrm{km}^{2}\right)$ was calculated using GIS streets data from Metro’s Regional Land System Information (RLIS 2012). The streets file was clipped to the study watersheds and overall length of the roads within each watershed was then calculated. The overall length of streets was then divided by the watershed area to give the road density.

\subsection{Hydrologic metrics}

Three hydrologic metrics were utilized in this investigation: the mean annual runoff ratio $\left(\mathrm{Q}_{\mathrm{a}}\right)$, the mean seasonal runoff ratio $\left(\mathrm{Q}_{\mathrm{w}}\right.$ or $\left.\mathrm{Q}_{\mathrm{d}}\right)$, and the fraction of time that streamflow exceeds the daily mean throughout the year (TQmean). The mean annual runoff ratio $\left(\mathrm{Q}_{\mathrm{a}}\right)$ is the ratio of runoff depth to precipitation. Runoff depth is the depth to 
which the drainage area would be covered in water if all the water for the year was distributed evenly over its surface (Chang 2007). Runoff depth is calculated by dividing the yearly discharge by the watershed area. $\mathrm{Q}_{\mathrm{a}}$ is closely associated with the amount of impervious cover and is thought to be lowest in the least urbanized watershed. The mean seasonal runoff ratio is the ratio of seasonal runoff depth (wet season $\mathrm{Q}_{\mathrm{w}}$ or dry season $\mathrm{Q}_{\mathrm{d}}$ ) to seasonal precipitation. In this case the wet season is defined by the period of October to March and the dry season is April to September. This seasonal division is typical for hydrological investigations in the Pacific Northwest (Cannon and Whitfield 2001) and has been used to investigate seasonal differences within watersheds (Chang 2007). TQmean is the fraction of time that streamflow exceeds the daily mean streamflow during the year. TQmean is an indicator of flashiness and tends to vary inversely with the amount of urban development (Konrad 2005). TQmean values were calculated for each watershed for the period of record and compared with the urbanization metrics.

In addition to the three hydrologic metrics used to evaluate stream behavior, the relative change in streamflow in response to storm events was examined. There is a direct response between precipitation events and increases in streamflow, and an evaluating the differences in streamflow in response to rain events provides further insight to hydrological differences that may exist due to varying amounts of urban development. Using criteria previously used in hydrologic studies of the Pacific Northwest (Cannon and Whitfield 2001; Chang 2007), storms are defined as continuous rainfall with more than $2 \mathrm{~mm}$ of rain in an hour. The study period for this analysis was limited to two and half water years (2009-2011) spanning five seasons (3 Dry and 2 Wet). An additional dry season was utilized to evenly represent both seasons, as the wet season typically has more 
storm events. Due to the large number of storms, especially during the wet season, storms preceded by dry periods were selected for with additional criteria. Dry period criteria consisted of no more than $2 \mathrm{~mm}$ of rainfall per day in the two days preceding the storm event. This was done to reduce the effect of antecedent moisture conditions on the storm analysis and provide a clearer picture of storm response due to rainfall. Using the same criteria as Chang (2007) changes in streamflow relative to pre-storm levels were defined as the normalized difference between baseflow and peakflow.

The normalized changes in streamflow were plotted against the normalized storm amount for all storm events for the Lower Fanno and Lower Johnson watersheds. There were 43 storms that fit the selection criteria for Lower Fanno watershed (19 wet season and 24 dry season), and 47 storms for the Lower Johnson watershed (21 wet season and 26 dry).

\subsection{Statistical analysis}

Descriptive and inferential statistics are used to evaluate any differences between watersheds and any links between hydrologic metrics and urbanization metrics. Boxwhisker plots are used to visually inspect for any differences that may exist for each metric between watersheds. The Kruskall-Wallis test is the one-way analysis of variance (ANOVA) for non-parametric data, and was used here to detect any statistical differences that may exist among hydrologic characteristics in each watershed. The Mann-Whitney test, a non-parametric test for testing two observations or paired data, was used to compare the mean seasonal runoff ratios $\left(\mathrm{Q}_{\mathrm{w}}\right.$ and $\left.\mathrm{Q}_{\mathrm{d}}\right)$ for each watershed. Kendall's rank correlation test was used to compare the three hydrologic metrics values to road density and percent impervious for all of the study watersheds. The long-term streamflow records 
in the Sycamore watershed allowed for comparing trends for the 1941-2010 water years. The 2011 water year was not used to provide an even 70 year record, which was then split in two different ways; 10 year divisions were used to evaluate any decadal temporal trends and 35 year divisions (1941-1976 and 1977-2011) were used to evaluate any temporal trends, providing pre- and post-development periods. 


\section{Results}

\subsection{Urbanization Metrics}

The level of urbanization in each watershed was expressed in terms of percent impervious and road density $\left(\mathrm{km} / \mathrm{km}^{2}\right)$. The two metrics were found to be highly correlated with a Pearson correlation value of 0.91 (Table 5). While the metrics were highly correlated, they quantify urbanization differently as the most urbanized watershed is different for each metric. Road density is greatest in the Upper Fanno watershed, while percent impervious is greatest within Lower Fanno watershed (Table 5). Both road density and percent impervious were the lowest within the Regner watershed. Both metrics were compared with the three hydrologic metrics for each watershed and the relationships are discussed below.

\subsection{Mean Annual Runoff Ratio $\left(Q_{a}\right)$}

The Kruskall-Wallis test revealed statistical difference among watersheds for $\mathrm{Q}_{\mathrm{a}}$ values (Table 6). Box-whisker plot analysis describes the overall distribution of $Q_{a}$ values and identified outliers (Figure 4). The Regner watershed was found to have the highest $\mathrm{Q}_{\mathrm{a}}$ of 0.67, while the Upper Fanno watershed had the lowest at 0.49 (Table 7). Scatterplot analysis shows a decreasing trend in $\mathrm{Q}_{\mathrm{a}}$ and the level of urbanization (Figure 5 and 6). One-sided Kendall's correlation rank test did not reveal a significant correlation between $\mathrm{Q}_{\mathrm{a}}$ and percent impervious $(\tau=-0.333, p=0.174)$. A negative correlation $(\tau=-0.467)$ with road density was only significant at $p<0.10$ (Table 8). The Sycamore watershed displayed no significant trend when comparing 1941-1976 and 1977-2011 periods (Table 9). When 10 year periods were evaluated the 1941-1950 period exhibited a significant 
increasing trend in $\mathrm{Q}_{\mathrm{a}}(\tau=0.442, p=0.045)$. The 2001-2010 period observed a weaker increasing trend in $\mathrm{Q}_{\mathrm{a}}(\tau=0.333, p=0.090)$.

\subsection{Mean Seasonal Runoff Ratio $\left(Q_{w}\right.$ or $\left.Q_{d}\right)$}

Mann-Whitney tests revealed statistically significant seasonal differences in all watersheds except for the Lower Johnson and Lower Fanno watersheds (Table 10). The greatest differences between the wet season runoff ratio and dry season runoff ratio were found within the Sycamore, Kelley, and Regner watersheds (Table 11). The Regner watershed had the highest wet season runoff ratio with 0.75, while the Upper Fanno watershed had the lowest with 0.52 (Figure 7). The Lower Johnson watershed had the highest dry season runoff ratio with 0.51 , while the Kelley watershed had the lowest with 0.33 .

Trend analysis of the seasonal runoff ratios in the Sycamore watershed revealed a significant positive trend in $\mathrm{Q}_{\mathrm{d}}$ values during the 1941-2010 period (Table 9). When the study period is divided by decade, there was a significant increasing trend for 1951-1960 followed by a decreasing trend in the 1961-1970 period. There was no significant trend for $\mathrm{Q}_{\mathrm{w}}$ during the 1941-2010 period however, a significant increase was observed for 1941-1950 while a weak increase was found for 2000-2010 $(p<0.10)$.

Road density was negatively and significantly correlated $(\tau=-0.600, p=0.045)$ with the wet seasonal runoff ratio $\left(\mathrm{Q}_{\mathrm{w}}\right)$ for the study watersheds. Scatterplot analysis displays the decreasing trend of $\mathrm{Q}_{\mathrm{w}}$ as road density increases (Figure 8). Percent impervious also revealed a negative correlation with $\mathrm{Q}_{\mathrm{w}}$ with $\tau=-0.467$, however it was only significant at $\alpha=0.094$. Scatterplot analysis also displays a decreasing trend in $\mathrm{Q}_{\mathrm{w}}$ as percent impervious decreases (Figure 9). Road density and percent impervious were 
both positively correlated with the dry season runoff ratio $\left(\mathrm{Q}_{\mathrm{d}}\right)$. However, neither was statistically significant with $\tau=0.200$ and 0.333 and $p=0.287$ and 0.174 , respectively.

\subsection{TQmean}

Flashiness, which describes the tendency of urban streams to exhibit quick rise and fall of peak streamflow, is represented here with TQmean. TQmean values of urban streams are generally less than 0.3 , while more rural streams have values greater than 0.3 (Konrad et al. 2007). The lowest TQmean values were in the Upper Fanno and Kelley watersheds, both with a TQmean of 0.24 (Figure 10). The highest TQmean value 0.34 was in the Regner watershed, the most rural of the watersheds in this study with the lowest percent impervious and road density values (Table 5). The Kruskall-Wallis test revealed statistical difference among watersheds for TQmean values, demonstrating the differences in values were not due to chance (Table 6). Negative correlations were found between TQmean and both road density and percent impervious, $\tau=-0.414$ and $\tau=-0.276$ respectively, but neither were statistically significant with $p=0.126$ and 0.222 . Scatterplot analysis displayed a decreasing trend in TQmean as both road density and percent impervious increase (Figure 11 and 12). Temporally, there was no significant trend in TQmean values during the 1941-2010 period (Table 9). When the study period is divided by decade some temporal trends became apparent. There was a negative and significant correlation for the $1971-1980$ period $(\tau=-0.467, p=0.030)$. The preceding 1961-1970 period observed a weaker correlation, however it was not significant at $p<$ $0.05(\tau=-0.333, p=0.090)$. 


\subsection{Storm Response Analysis}

The Lower Fanno watershed experiences quick response to precipitation events regardless of the season (Figure 13). When the normalized changes in streamflow are plotted with the normalized storm amount, both the wet season and dry season exhibit steep slopes, indicating a quick response to rainfall (1.22 and 0.88 respectively). The Lower Johnson exhibited a quick response to storms in the wet season with a response slope of 0.79 when plotted. However, unlike the Lower Fanno, the Lower Johnson displayed had a much slower response to summer storms with a response slope of 0.12 (Figure 14). 


\section{Discussion}

\section{1 Discussion: $Q_{a}$}

Mean annual runoff ratio is thought to be closely linked with the amount of urbanization within a watershed, with higher $\mathrm{Q}_{\mathrm{a}}$ values in urbanized watersheds and lower $\mathrm{Q}_{\mathrm{a}}$ values in more rural watersheds. Interestingly, the highest runoff ratio was found within the Regner, the least urbanized watershed in the study. While low runoff ratios are generally observed within rural areas, the higher $\mathrm{Q}_{\mathrm{a}}$ could be attributed to factors not considered by the hydrologic metric. The Regner watershed's higher elevation means that it receives orographic precipitation, as well as lower evapotranspiration rates contributing to increased runoff. Consolidated sands and gravels make up the underlying geology (Figure 15) and soils are consist primarily silty clay and silt loam (Figure 16). The less permeable soils and somewhat steep slopes (Figure 17) coupled with higher precipitation contribute to greater surface runoff and streamflow (Lee and Snyder 2009).

The lowest $\mathrm{Q}_{\mathrm{a}}$ was observed in the well developed Upper Fanno watershed. Some stormwater drainage pipes do not always drain into the same watershed where they collect precipitation, instead routing runoff into a nearby drainage area. This could result in overestimated precipitation while calculating the runoff ratio and produce in unexpected low runoff ratio values. While the Upper Fanno consists of dense suburban development and a network of stormwater drainage pipes collecting surface water the differences in topographic watershed and piped drainage watershed areas for the Upper Fanno are negligible (6.09 $\mathrm{km}^{2}$ and $6.03 \mathrm{~km}^{2}$ respectively), so this factor does not appear to be influencing the low $\mathrm{Q}_{\mathrm{a}}$ value. The underlying geology consists of volcanic basalt (Figure 15) while the soils consist primarily of silty loams and urban complex (Figure 
16). The less permeable soils, high levels of impervious surfaces and steep slopes (Figure 17) would normally suggest higher $Q_{a}$ values, however this is not case with the Upper Fanno. It is unclear from this investigation what is contributing to the low runoff ratios in the Upper Fanno watershed and further investigation is necessary to explain these values.

Percent impervious was not significantly correlated with $Q_{a}$, however road density was negatively correlated $(\tau=-0.467)$ but only significant at $p<0.10$. The weak relationship suggests that urbanization can result in changes in the annual runoff ratio, but that other factors besides urbanization may influence $\mathrm{Q}_{\mathrm{a}}$. Similar research has also suggested that urbanization may not be the most important factor for predicting total annual runoff (Rose and Peters 2001; Chang 2007). Total annual flow may not change significantly, but the composition of surface water and groundwater contributions may change. In response to urbanization, surface runoff contributions may increase, while groundwater contributions decrease. Previous research has also suggested that annual scales may not capture the dynamic behavior of urban streamflow (Chang 2007). Shorter time scales, possibly monthly or event scale, may be better suited for analysis. Increased surface runoff may be offset by lower groundwater contributions due to impervious surfaces and $\mathrm{Q}_{\mathrm{a}}$ may fail to capture this behavior.

Overall, a general decrease in runoff ratios was observed from higher elevation watersheds to lower elevation watersheds (Figure 18). Similarly, this pattern of decreasing runoff ratios with decreasing elevation was observed in Rose and Peter's (2001) comparison of streamflow characteristics in the Atlanta, Georgia area. They contributed this pattern to higher rates of evapotranspiration (ET) at lower elevation watersheds which returns more precipitation back to the atmosphere. Chang (2007) 
observed a similar pattern in their evaluation of Johnson Creek, attributing higher ET values to the watershed's elongated shape and warmer stream temperatures.

The Sycamore watershed's long period of record allowed temporal trends in $\mathrm{Q}_{\mathrm{a}}$ to be evaluated. The moderately developed Sycamore watershed had the second highest $\mathrm{Q}_{\mathrm{a}}$ of the watersheds at 0.66 , so to investigate any temporal trends $Q_{a}$ existed due to urbanization, Kendall's rank correlation was evaluated. While no significant change was observed when considering the entire period of record, the earliest and most recent portions indicated the influence of urbanization. The early increase in the mean runoff ratio for 1941-1950 could be due to the initial pressure of urbanization, while the middle part of the record indicates that $\mathrm{Q}_{\mathrm{a}}$ may have stabilized after the initial urbanization of the area (Table 6). The recent increase in $\mathrm{Q}_{\mathrm{a}}$ during the 2000-2010 period could indicate more recent pressure of urbanization in the watershed due to the expansion of the UGB that occurred in 2002. The expansion of the UGB means that the Sycamore watershed will experience higher rates of urbanization and this could produce changes in $Q_{a}$ as the hydrologic properties of the watershed are altered. It should be noted that Kelley and Regner watersheds, which are nested in the Sycamore watershed, did not see any significant changes in $\mathrm{Q}_{\mathrm{a}}(\tau=-0.256, p=0.111$ and $\tau=0.200, p=0.196$ respectively). However, both Kelley and Regner watersheds were limited to short periods of records with 10 and 13 years of data respectively.

\subsection{Discussion: $\mathbf{Q}_{\mathrm{w}}$ and $\mathrm{Q}_{\mathrm{d}}$}

Seasonal differences in streamflow can vary greatly within the Pacific Northwest due to the climate, which consists of mild and wet winters and dry, warm summers. Winter precipitation accounts for about $80 \%$ of total annual precipitation for the Portland 
metro area (Chang 2007). The mean seasonal runoff ratios $\left(\mathrm{Q}_{\mathrm{w}}\right.$ and $\left.\mathrm{Q}_{\mathrm{d}}\right)$ were used to investigate any seasonal differences that may exist in watersheds. It was expected that seasonal differences in the runoff ratio would be greatest within the most urbanized watersheds. Wet season runoff ratios were found to be highest in the Sycamore and Regner watersheds (Figure 7). Sycamore is a moderately urbanized watershed with a road density of $4.6\left(\mathrm{~km} / \mathrm{km}^{2}\right)$ and $15.2 \%$ impervious. An elevated wet season runoff ratio can be attributed to the flash runoff from impervious surfaces during the wet season.

It was hypothesized that seasonal differences between runoff ratios would be greatest within the most urbanized watersheds. Mann-Whitney tests revealed statistically significant seasonal differences in all watersheds except for the Lower Johnson and Lower Fanno (Table 11) watersheds and the box-whisker plots display the small seasonal differences (Figure 7).

The moderately developed Sycamore watershed exhibited the second largest difference between runoff ratios with 0.65 and 0.39 for winter and summer respectively. While Sycamore is moderately developed with $15.2 \%$ impervious and 4.6 road density, the more urbanized watersheds of Upper Fanno, Lower Fanno and Lower Johnson did not display large seasonal difference as expected. Lower Johnson had the highest dry season runoff ratio of 0.51 and the smallest seasonal difference in runoff ratios $\left(Q_{w}=0.53\right.$ and $Q_{d}=0.51$ ). The high dry season runoff ratio and consequently the small difference in seasonal runoff ratios could be attributed to the presence of Crystal Springs Creek which enters Johnson Creek just north of the Johnson Creek at Milwaukie USGS gage. Lee and Snyder (2009) noted that Crystal Springs provides most of the late summer season flow for the Lower Johnson Creek. Crystal Springs Creek also accounts for about half of the 
increase in streamflow observed from the Sycamore to Milwaukie stations. The contributions of Crystal Springs Creek to Lower Johnson streamflow therefore reduces the seasonal differences that would be expected in such a highly developed watershed. Additionally, underground injection control (UIC) systems such as dry wells, stormwater injection systems and sumps, all divert stormwater into the subsurface (Lee and Snyder 2009). Smaller stormwater contribution to streamflow particularly impacts the wet season runoff ratio as a proportion of storm runoff is diverted, and this is not reflected in $\mathrm{Q}_{\mathrm{w}}$.

Interestingly, the least urbanized watershed Regner, had the highest wet season runoff ratio and exhibited the greatest difference in seasonal runoff ratios where $\mathrm{Q}_{\mathrm{w}}=$ 0.75 and $\mathrm{Q}_{\mathrm{d}}=0.46$. Regner may have lower ET losses due to the higher elevation of the watershed compared to lower elevation watersheds, and therefore more precipitation contributes to wet season flow.

Scatterplot analysis indicated a decreasing trend in $\mathrm{Q}_{\mathrm{w}}$ as the level of urban development increases (Figure 8 and Figure 9). It was expected that wet season runoff ratios would be higher in watersheds with more urbanization due to increase surface runoff. However, as with $\mathrm{Q}_{\mathrm{a}}$, increased surface runoff may be offset by lower groundwater contributions due to impervious surfaces. While road density and percent impervious were both positively correlated with the dry season runoff ratio $\left(\mathrm{Q}_{\mathrm{d}}\right)$ in the study watersheds, neither was statistically significant (Table 8). A significant correlation between $Q_{d}$ and watershed size $(\tau=0.600, p=0.045)$ indicates that larger watershed size results in higher $\mathrm{Q}_{\mathrm{d}}$ values (Table 12).

It was expected that watersheds with greater levels of development would exhibit significant differences between $\mathrm{Q}_{\mathrm{w}}$ and $\mathrm{Q}_{\mathrm{d}}$ due to urbanization. Increased surface runoff 
due to impervious surfaces, in addition to extensive stormwater drainage systems that route runoff into nearby streams at a faster rate, typically produces higher wet season runoff. As with $Q_{a}$, it is possible that seasonal differences in highly urbanized watersheds may not be captured at this temporal scale (seasonal as opposed to annual with $\mathrm{Q}_{\mathrm{a}}$ ), and may instead require the use of daily or hourly metrics to measure changes. Elevation may play a role as ET losses may account for Regner watersheds large difference between $\mathrm{Q}_{\mathrm{w}}$ and $\mathrm{Q}_{\mathrm{d}}$.

\subsection{Discussion: TQmean}

TQmean is a measure of a watershed's flashiness and is inversely related to urban development. It was hypothesized that the watersheds with the highest levels of urban development would exhibit the lowest TQmean values. Watersheds with higher levels of urban development tend to have fewer days where daily mean flow exceeds the annual mean flow (Figure 10). The lowest TQmean values were in the Upper Fanno and Kelley watersheds, both with a TQmean of 0.24. Low TQmean values in Upper Fanno and Kelley watersheds indicate a flashy response to precipitation, with faster storm recession and lower baseflow contributions during the wet season. The low TQmean value in the Upper Fanno is expected since it is highly developed with a road density of $12.7\left(\mathrm{~km} / \mathrm{km}^{2}\right)$ and 30.8\% impervious. A low TQmean value in the Kelley watershed is interesting considering the low levels of development with $10.4 \%$ impervious surface and a road density of $3.8\left(\mathrm{~km} / \mathrm{km}^{2}\right)$. Kelley watershed does not appear to be losing any precipitation inputs due to stormwater drainage being routed outside the system, as the difference in watershed size when considering the drainage network is minimal (Table 13). It is possible that other watershed characteristics not directly considered here, such as soils or 
geology may also influence TQmean. Another consideration is that while Kelley has low levels of development, it is still beyond what some experts have termed a "critical threshold” value of 10\% for urban development (Booth, 1991; Schueler 1994). This means that watersheds see the most changes to the hydrologic regime when moving from $0 \%$ or nearly $0 \%$ up to $10 \%$. This could make it difficult to identify clear TQmean patterns in watersheds with beyond the $10 \%$ developed threshold. While a clear relationship between low TQmean and urbanization was not established, the least developed Regner watershed had the highest TQmean as expected.

Temporal analysis in Sycamore revealed a significant decrease in TQmean for the 1971-1980 period (Table 9). It is hard to directly link this decrease with urban development as much of the infrastructure already existed prior to the beginning of this period (Lee and Snyder, 2009). The preceding 1961-1970 period observed a weaker rank correlation, however it was not significant at $p<0.05(\tau=-0.333, p=0.090)$. This short decreasing trend in TQmean indicates an increase in flashiness. However it is unclear what caused this trend and it is not believed to be linked with any urban development.

On the rural to urban gradient a declining trend in TQmean values can be observed (Figure 11 and 12). While statistical analysis revealed a negative correlation between TQmean and both road density and percent impervious neither were statistically significant ( $p=0.126$ and 0.222 respectively). The rural Kelley watershed (3.8 road density and $10.4 \%$ impervious) exhibited a TQmean value 0.24 over the study period, lower than was expected and comparable to more urban streams in the study. Upper Fanno exhibited the same TQmean value of 0.24 but is significantly more urbanized with a 12.7 road density $\left(\mathrm{km} / \mathrm{km}^{2}\right)$ and $30.8 \%$ impervious. As was the case with $\mathrm{Q}_{\mathrm{a}}$, a lower 
than expected TQmean value may be the result of water leaving the system through the stormwater drainage system. High levels of urbanization have been shown to result in flashy urban streams (Roy et al. 2005). A weak rank correlation $(\tau=0.414, p=0.126)$ between TQmean and watershed size indicates that the drainage area does not likely have much of an effect upon the relationship between TQmean and both road density and percent impervious.

Due to the flashy nature of Johnson Creek and its history of flooding, it was hypothesized that a decreasing trend in TQmean would be exhibited by examining the Sycamore station long term record. This decreasing trend could be associated with increasing development and possibly the creation of the Oregon land use laws in 1973 and creation of the UGB in 1978. The periods after 1980 show no significant decrease and could be associated with the relatively stable development of the watershed.

\subsection{Discussion: Storm Response Analysis}

Wet season storms produced steep changes in streamflow for both the Lower Fanno and Lower Johnson Watershed. This suggests the influence of antecedent soil moisture on stream response as well as increased surface runoff due to impervious surfaces. Summer storms produced a much steeper response in the Lower Fanno than the Lower Johnson. The steep response in summer storms for the Lower Fanno is attributed to rapid surface runoff. While the Lower Johnson is highly urbanized, the combined sewer system collects surface water from much of this area and well drained soils create a slower response for summer storms. 


\section{Conclusions}

It was determined that urbanization in Fanno and Johnson Creek, and their subwatersheds, has resulted in changes to streamflow characteristics. While it was hypothesized that the annual mean runoff ratio would be lower in watersheds with high levels of urbanization, no significant trends were found. There were some temporal changes in $\mathrm{Q}_{\mathrm{a}}$ in the Sycamore watershed, indicating that urbanization can have an effect upon the annual runoff ratio, however it may not be the best hydrologic metric to demonstrate the hydrologic effects of urbanization. This indicates the effects of urbanization may not be adequately captured on an annual scale and that the mean annual runoff ratio simply fails to capture most of these changes. Further illustrating this was the lack of a significant relationship between measures of urbanization and $\mathrm{Q}_{\mathrm{a}}$.

The negative correlation between urbanization and $\mathrm{Q}_{\mathrm{w}}$ indicated a decreasing trend in $\mathrm{Q}_{\mathrm{w}}$ with urbanization. $\mathrm{Q}_{\mathrm{w}}$ was expected to be higher in more developed watersheds but as previously mentioned, even at a shorter seasonal scale, $\mathrm{Q}_{\mathrm{w}}$ may fail to accurately describe seasonal effects of urbanization. Additionally, differences between seasonal runoff ratios were found to be greatest in more rural watersheds than in urbanized watersheds. It is likely that the differences in soil permeability and the interception of precipitation by the combined sewer, and UIC moderates the high flows in the Lower Johnson. The Sycamore's trend analysis revealed some significant increases in $\mathrm{Q}_{\mathrm{w}}$ during late and early periods of record, indicating some influence of urban development on wet season flow. However, the overall increase $Q_{d}$ was not expected as urbanization should decrease baseflow contributions which account for a large proportion of summer flow in the Pacific Northwest. 
Generally, the more urbanized streams exhibited lower TQmean values than rural streams in this study. Neither road density nor percent impervious proved to be a reliable predictor of TQmean values. However, while trend analysis in the Sycamore watershed did indicate some significant increases in flashiness it is not believed to be associated with historical development in the watershed.

There are two main conclusions of this study. First, the time scale used seems to have a large impact upon the ability to characterize the influence of urbanization on streamflow characteristics. Using Sycamore's long term records, it was possible to isolate some trends in each metric, however, the general pattern was not always evident. This has been attributed to the time scale for analysis being too large to capture the dynamic behavior of urban streams. Using an event scale analysis may be better suited to capture the quick response of urban streams to precipitation events. The limited event scale analysis performed in this study revealed interesting insights to the different behavior of the Lower Johnson and Lower Fanno watersheds.

Second, the Johnson Creek watershed, in particular the Lower Johnson, does not behave as a "typical" urban watershed. This is partly attributed to the historical development and associated drainage infrastructure, which includes a combined sewer system and UICs. Stormwater drainage networks that route water directly into the stream or out of the watershed completely complicate the process of characterizing streamflow. Also contributing to the unique streamflow behavior of Johnson Creek is the hydrogeologic properties that vary over the watershed. The northern side of the watershed is generally flat except for isolated volcanic buttes, and has well drained soils while the southern side is comprised of steep slopes and less-permeable soils which 
contribute more to more rapid runoff. Groundwater contributions which comprise most of Crystal Springs also are responsible for unexpected hydrologic metric values, most notably the lack of difference in seasonal runoff ratios $\mathrm{Q}_{\mathrm{w}}$ and $\mathrm{Q}_{\mathrm{d}}$.

Future recommendations for study include applying a smaller temporal scale for hydrologic analysis to better characterize effects of urbanization on streamflow patterns. Utilizing hydrologic metrics that operate on shorter time scales and a comparison of those with urbanization metrics is recommended. The limited use of storm scale analysis in this study was effective at illustrating the different response to rainfall in Fanno and Johnson watersheds. Incorporating the influence of the metropolitan areas stormwater drainage system in further detail would be beneficial as this system can significantly alter natural drainage characteristics. While the difference in topological watershed and piped drainage watershed areas was considered as a cofounding factor in this study's results, further analysis is recommended. 
Table 1. Data types and sources used for the study.

\begin{tabular}{|c|c|c|}
\hline Category & Data & Source \\
\hline Hydrology & Historical streamflow & USGS Oregon Water Science Center \\
\hline Climate & Historical precipitation & $\begin{array}{c}\text { Hydra Rainfall Network } \\
\text { NOAA National Climate Data Center }\end{array}$ \\
\hline Soil & Hydrologic Soil Groups & National Resource Conservation Service \\
\hline $\begin{array}{c}\text { Percent } \\
\text { Impervious }\end{array}$ & 2006 Impervious Surfaces Dataset & $\begin{array}{l}\text { National Land Cover Database (NLCD) } 2006 \\
\text { Impervious Surfaces Dataset }\end{array}$ \\
\hline Watersheds & 10m Digital Elevation Model (DEM) & US Geological Survey (USGS) \\
\hline Imagery & $\begin{array}{c}\text { 1m Compressed County Mosaic Aerial } \\
\text { Image, } 2009 \\
\end{array}$ & $\begin{array}{c}\text { National Agricultural Imagery Program } \\
\text { (NAIP) }\end{array}$ \\
\hline Ancillary & Streams, Roads, etc. & Regional Land Information System (RLIS) \\
\hline
\end{tabular}


Table 2. USGS monitoring stations and hydrologic characteristics.

\begin{tabular}{|c|c|c|c|c|c|c|c|c|}
\hline $\begin{array}{l}\text { Station } \\
\text { Name }\end{array}$ & $\begin{array}{l}\text { Watershed } \\
\text { Name }\end{array}$ & $\begin{array}{c}\text { USGS } \\
\text { Station } \\
\text { No. }\end{array}$ & Location & $\begin{array}{c}\text { Gage } \\
\text { Elevation } \\
\quad(\mathbf{m})\end{array}$ & $\begin{array}{l}\text { Watershed } \\
\text { Area }\left(\mathbf{k m}^{2}\right)\end{array}$ & $\begin{array}{c}\text { Watershed } \\
\text { Slope } \\
\text { (degrees) }\end{array}$ & $\begin{array}{c}\text { Watershed } \\
\text { Elevation Range } \\
\text { (m) }\end{array}$ & $\begin{array}{c}\text { Mean Annual } \\
\text { Flow }\left(\mathbf{m}^{3} \mathbf{s}^{-1}\right)\end{array}$ \\
\hline $\begin{array}{l}\text { Johnson } \\
\text { Creek at } \\
\text { Sycamore Rd. }\end{array}$ & Sycamore & 14211500 & $\begin{array}{l}\text { Lat } 45^{\circ} 28^{\prime} 40^{\prime \prime}, \\
\text { Long } 122^{\circ} 30^{\prime} 24^{\prime \prime}\end{array}$ & 69.6 & 69.4 & 6.4 & $70.1-342.9$ & 1.5 \\
\hline $\begin{array}{l}\text { Kelley Creek } \\
\text { at 159th Ave. }\end{array}$ & Kelley & 14211499 & $\begin{array}{l}\text { Lat } 45^{\circ} 28 ' 37^{\prime}, \\
\text { Long } 122^{\circ} 29^{\prime} 50^{\prime \prime}\end{array}$ & 74.7 & 12.7 & 6.8 & 73.2 - 342.9 & 0.2 \\
\hline $\begin{array}{l}\text { Johnson } \\
\text { Creek at } \\
\text { Regner Rd. }\end{array}$ & Regner & 14211400 & $\begin{array}{l}\text { Lat } 45^{\circ} 29^{\prime} 12^{\prime \prime}, \\
\text { Long } 122^{\circ} 25^{\prime} 14^{\prime \prime}\end{array}$ & 93.0 & 39.8 & 6.2 & $93.0-331.0$ & 0.9 \\
\hline $\begin{array}{l}\text { Fanno Creek } \\
\text { at Durham } \\
\text { Ave. }\end{array}$ & $\begin{array}{l}\text { Lower } \\
\text { Fanno }\end{array}$ & 14206950 & $\begin{array}{c}\text { Lat } 45^{\circ} 24 ' 13^{\prime \prime}, \\
\text { Long } \\
122^{\circ} 45^{\prime} 13^{\prime \prime}\end{array}$ & 35.3 & 80.6 & 5.1 & 36.0 - 326.1 & 1.2 \\
\hline
\end{tabular}


Table 3. Length of hydrological record for USGS stations.

\begin{tabular}{|l|c|c|c|}
\hline \multicolumn{1}{|c|}{ Station Name } & USGS Station No. & Date Range (Water Years) & Water Years \\
\hline Johnson Creek at Milwaukie & 14211550 & $1990-2011$ & 22 \\
\hline Johnson Creek at Sycamore Rd. & 14211500 & $1941-2011$ & 71 \\
\hline Kelley Creek at 159th Ave. & 14211499 & $2001-2011$ & 11 \\
\hline Johnson Creek at Regner Rd. & 14211400 & $1999-2011$ & 13 \\
\hline Fanno Creek at Durham Ave. & 14206950 & $1994-1995,2001-2011$ & 21 \\
\hline Fanno Creek at 56 & 14206900 & $1991-2011$ & 2 \\
\hline
\end{tabular}

Table 4. Weather stations used for precipitation records.

\begin{tabular}{|c|c|c|c|c|c|}
\hline Station Name & Source & Station No. & Location & $\begin{array}{l}\text { Elevation } \\
\quad \text { (m) }\end{array}$ & $\begin{array}{c}\text { Mean Annual } \\
\text { Precipitation } \\
\text { (cm) }\end{array}$ \\
\hline $\begin{array}{l}\text { Portland Intl. } \\
\text { Airport }\end{array}$ & NWS & 356751 & $\begin{array}{c}\text { Lat } 45^{\circ} 35^{\prime} 27^{\prime}, \text { Long } \\
122^{\circ} 36^{\prime} 01^{\prime \prime}\end{array}$ & 6 & 98 \\
\hline Harney & Hydra & 64 & $\begin{array}{c}\text { Lat } 45^{\circ} 27^{\prime} 44^{\prime \prime}, \text { Long } \\
122^{\circ} 38^{\prime} 36^{\prime \prime}\end{array}$ & 19 & 93 \\
\hline Holgate & Hydra & 21 & $\begin{array}{c}\text { Lat } 45^{\circ} 29^{\prime} 21^{\prime}, \text { Long } \\
122^{\circ} 31^{\prime} 26^{\prime \prime}\end{array}$ & 63 & 103 \\
\hline Pleasant Valley & Hydra & 145 & $\begin{array}{c}\text { Lat } 45^{\circ} 27^{\prime} 52^{\prime \prime}, \text { Long } \\
122^{\circ} 28^{\prime} 50^{\prime \prime}\end{array}$ & 108 & 113 \\
\hline Gresham Fire Dept. & Hydra & 20 & $\begin{array}{c}\text { Lat } 45^{\circ} 30^{\prime} 27^{\prime}, \text { Long } \\
122^{\circ} 26^{\prime} 12^{\prime \prime} \\
\end{array}$ & 95 & 104 \\
\hline Hillsboro & NWS & 353908 & $\begin{array}{c}\text { Lat } 45^{\circ} 30^{\prime} 50^{\prime \prime}, \text { Long } \\
122^{\circ} 59^{\prime} 24^{\prime \prime}\end{array}$ & 49 & 98 \\
\hline Sylvania PCC & Hydra & 4 & $\begin{array}{c}\text { Lat } 45^{\circ} 26^{\prime} 13^{\prime \prime}, \text { Long } \\
122^{\circ} 43^{\prime} 54^{\prime \prime}\end{array}$ & 197 & 90 \\
\hline Sylvan School & Hydra & 161 & $\begin{array}{c}\text { Lat } 45^{\circ} 30^{\prime} 36^{\prime \prime}, \text { Long } \\
122^{\circ} 44^{\prime} 13^{\prime \prime}\end{array}$ & 247 & 85 \\
\hline
\end{tabular}

Table 5. Urban development in each watershed represented by road density and percent impervious and correlation.

\begin{tabular}{|l|c|c|}
\hline \multicolumn{1}{|c|}{ Watershed } & Road Density $\left.\mathbf{( k m} / \mathbf{k m}^{2}\right)$ & Percent Impervious \\
\hline Lower Johnson & 8.5 & 30.5 \\
Sycamore & 4.6 & 15.2 \\
Kelley & 3.8 & 10.4 \\
Regner & 3.5 & 9.5 \\
Lower Fanno & 10.7 & 39.5 \\
Upper Fanno & 12.7 & 30.8 \\
\hline \hline \multicolumn{2}{|c|}{ Pearson Correlation Coefficient } & $\mathrm{r}=0.912, p=0.01$ \\
\hline
\end{tabular}


Table 6. Kruskall-Wallis test for testing independence of hydrologic metrics among watersheds. Bold values are statistically significant at $p<0.05$.

\begin{tabular}{|c|c|c|}
\hline Hydrologic Metric & Chi-Squared & $\boldsymbol{p}$-value \\
\hline $\mathrm{Q}_{\mathrm{a}}$ & 23.28 & $\mathbf{0 . 0 0}$ \\
$\mathrm{Q}_{\mathrm{w}}$ & 28.48 & $\mathbf{0 . 0 0}$ \\
$\mathrm{Q}_{\mathrm{d}}$ & 14.30 & $\mathbf{0 . 0 1}$ \\
TQmean & 12.52 & $\mathbf{0 . 0 3}$ \\
\hline
\end{tabular}

Table7. Mean annual runoff ratios $\left(\mathrm{Q}_{\mathrm{a}}\right)$ for each watershed.

\begin{tabular}{|c|c|}
\hline Watershed & $\mathbf{Q}_{\mathbf{a}}$ \\
\hline Lower Johnson & 0.53 \\
Sycamore & 0.66 \\
Kelley & 0.51 \\
Regner & 0.67 \\
Upper Fanno & 0.49 \\
Lower Fanno & 0.56 \\
\hline
\end{tabular}

Table 8. Kendall's tau rank correlation values between hydrologic metrics and urbanization metrics. Bold values are statistically significant at $p<0.05$.

\begin{tabular}{|c|cc|cc|}
\hline & \multicolumn{2}{|c|}{ Road Density } & \multicolumn{2}{c|}{ Percent Impervious } \\
\cline { 2 - 5 } & tau & $p$ & tau & $p$ \\
\hline \hline $\mathrm{Q}_{\mathrm{a}}$ & -0.467 & 0.094 & -0.333 & 0.174 \\
$\mathrm{Q}_{\mathrm{w}}$ & -0.600 & $\mathbf{0 . 0 4 5}$ & -0.467 & 0.094 \\
$\mathrm{Q}_{\mathrm{d}}$ & 0.200 & 0.287 & 0.333 & 0.174 \\
TQmean & -0.414 & 0.126 & -0.276 & 0.222 \\
\hline
\end{tabular}


Table 9. Trend analysis for each hydrologic metric for the Sycamore watershed. Bold values are significant at $p<0.05$.

\begin{tabular}{|c|cc|cc|cc|cc|}
\hline & \multicolumn{2}{|c|}{$\mathbf{Q}_{\mathbf{a}}$} & \multicolumn{2}{c|}{$\mathbf{Q}_{\mathbf{w}}$} & \multicolumn{2}{c|}{$\mathbf{Q}_{\mathbf{d}}$} & \multicolumn{2}{c|}{ TQmean } \\
\cline { 2 - 9 } & tau & $p$ & tau & $p$ & tau & $p$ & tau & $p$ \\
\hline \hline $1941-2010$ & -0.074 & 0.186 & -0.073 & 0.186 & 0.154 & $\mathbf{0 . 0 3 0}$ & 0.160 & 0.422 \\
\hline \hline $1941-1950$ & 0.442 & $\mathbf{0 . 0 4 5}$ & 0.511 & $\mathbf{0 . 0 2 0}$ & 0.067 & 0.394 & 0.067 & 0.394 \\
$1951-1960$ & -0.111 & 0.327 & -0.156 & 0.266 & 0.422 & $\mathbf{0 . 0 4 5}$ & -0.022 & 0.464 \\
$1961-1970$ & -0.111 & 0.327 & -0.022 & 0.464 & -0.422 & $\mathbf{0 . 0 4 5}$ & -0.333 & 0.090 \\
$1971-1980$ & -0.022 & 0.464 & -0.156 & 0.266 & -0.022 & 0.464 & -0.467 & $\mathbf{0 . 0 3 0}$ \\
$1981-1990$ & -0.255 & 0.185 & -0.156 & 0.266 & -0.022 & 0.464 & -0.045 & 0.429 \\
$1991-2000$ & 0.022 & 0.464 & -0.022 & 0.464 & -0.156 & 0.266 & 0.067 & 0.394 \\
$2001-2010$ & 0.333 & 0.090 & 0.378 & 0.064 & 0.378 & 0.064 & -0.270 & 0.281 \\
\hline
\end{tabular}

Table 10. Mann-Whitney test values comparing $\mathrm{Q}_{\mathrm{w}}$ and $\mathrm{Q}_{\mathrm{d}}$ to evaluate seasonal differences. Bold values are statistically significant at $p<0.05$.

\begin{tabular}{|l|c|}
\hline \multicolumn{2}{|c|}{ Mann-Whitney Test Values } \\
\hline Watershed & $\boldsymbol{p}$ value \\
\hline Lower Johnson & 0.519 \\
Sycamore & $\mathbf{0 . 0 0 0}$ \\
Kelley & $\mathbf{0 . 0 0 1}$ \\
Regner & $\mathbf{0 . 0 0 0}$ \\
Lower Fanno & 0.058 \\
Upper Fanno & $\mathbf{0 . 0 1 3}$ \\
\hline
\end{tabular}

Table 11. Differences in seasonal runoff ratio in comparison to levels of urbanization.

\begin{tabular}{|l|c|c|c|c|c|}
\hline Watershed & $\mathbf{Q}_{\mathbf{w}}$ & $\mathbf{Q}_{\mathbf{d}}$ & Seasonal Difference & $\begin{array}{c}\text { Road Density } \\
\left(\mathbf{k m} / \mathbf{k m}^{2}\right)\end{array}$ & $\begin{array}{c}\text { Percent } \\
\text { Impervious }\end{array}$ \\
\hline Lower & 0.53 & 0.51 & 0.03 & 8.5 & 30.5 \\
Johnson & & 0.26 & 4.6 & 15.2 \\
Sycamore & 0.65 & 0.39 & 0.24 & 3.8 & 10.4 \\
Kelley & 0.57 & 0.33 & 0.29 & 3.5 & 9.5 \\
Regner & 0.75 & 0.46 & 0.10 & 10.7 & 39.5 \\
Lower Fanno & 0.59 & 0.49 & 0.10 & 12.7 & 30.8 \\
\hline Upper Fanno & 0.52 & 0.42 & \multicolumn{2}{l}{} \\
\hline
\end{tabular}


Table 12. Kendall's tau rank correlation values between hydrologic metrics and watershed size. Bold values are statistically significant at $p<0.05$.

\begin{tabular}{|c|cc|}
\hline \multirow{2}{*}{} & \multicolumn{2}{|c|}{ Watershed Area } \\
\cline { 2 - 3 } & tau & $p$ \\
\hline \hline $\mathrm{Q}_{\mathrm{a}}$ & 0.200 & 0.287 \\
$\mathrm{Q}_{\mathrm{w}}$ & 0.067 & 0.425 \\
$\mathrm{Q}_{\mathrm{d}}$ & 0.600 & $\mathbf{0 . 0 4 5}$ \\
TQmean & 0.414 & 0.126 \\
\hline
\end{tabular}

Table 13. Watershed areas for topographic and piped drainage watershed delineations.

\begin{tabular}{|l|c|c|}
\hline Watershed & Topographic Watershed Area $\left.\mathbf{( k m}^{2}\right)$ & Piped Drainage Watershed Area $\mathbf{( k m}^{\mathbf{2}} \mathbf{)}$ \\
\hline Lower & 137.77 & 155.29 \\
Johnson & 69.41 & 70.19 \\
Sycamore & 12.13 & 12.36 \\
Kelley & 39.81 & 38.45 \\
Regner & 80.62 & 80.56 \\
Lower Fanno & 6.09 & 6.03 \\
Upper Fanno & & \\
\hline
\end{tabular}




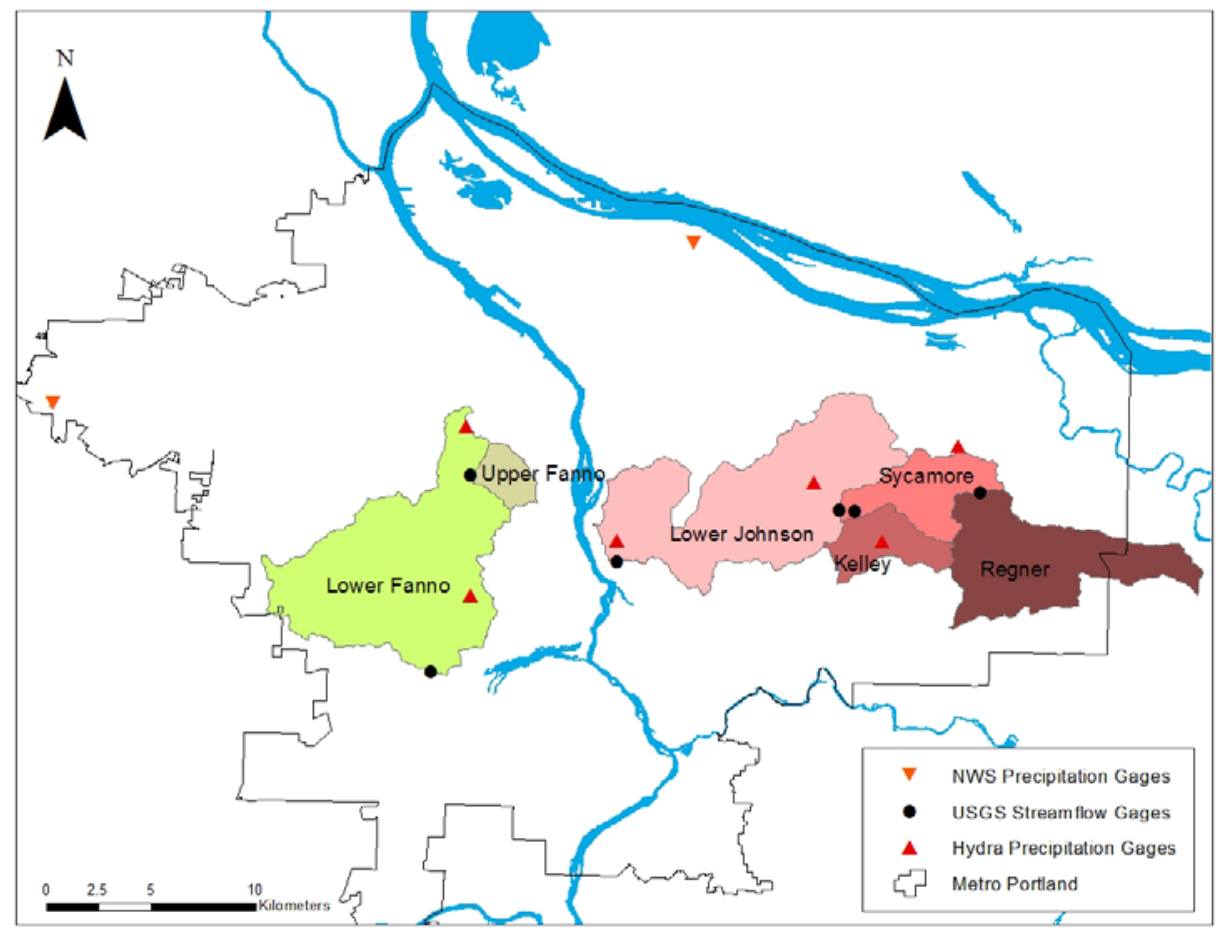

Figure 1. Map of Fanno and Johnson Creek watersheds study area and subwatersheds.

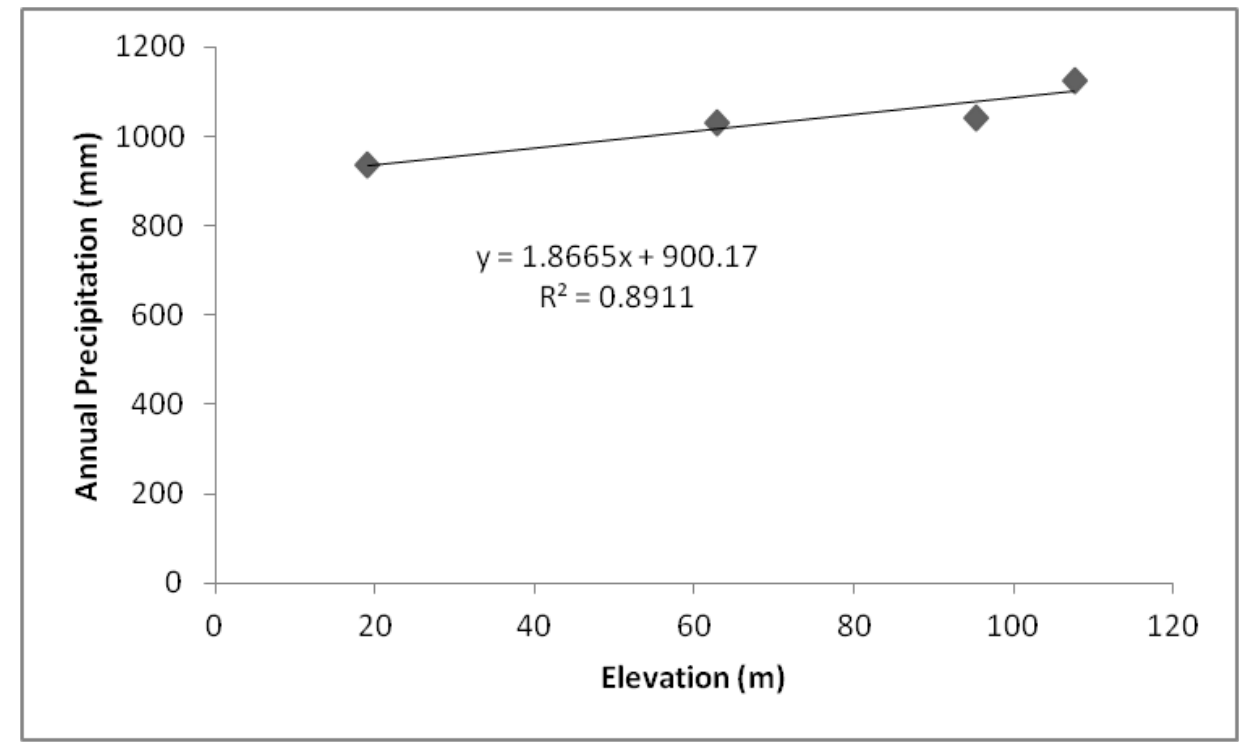

Figure 2. Relationship between elevation and annual mean precipitation for Johnson Creek Hydra rain gages used to adjust Portland International Airport NWS Station. 


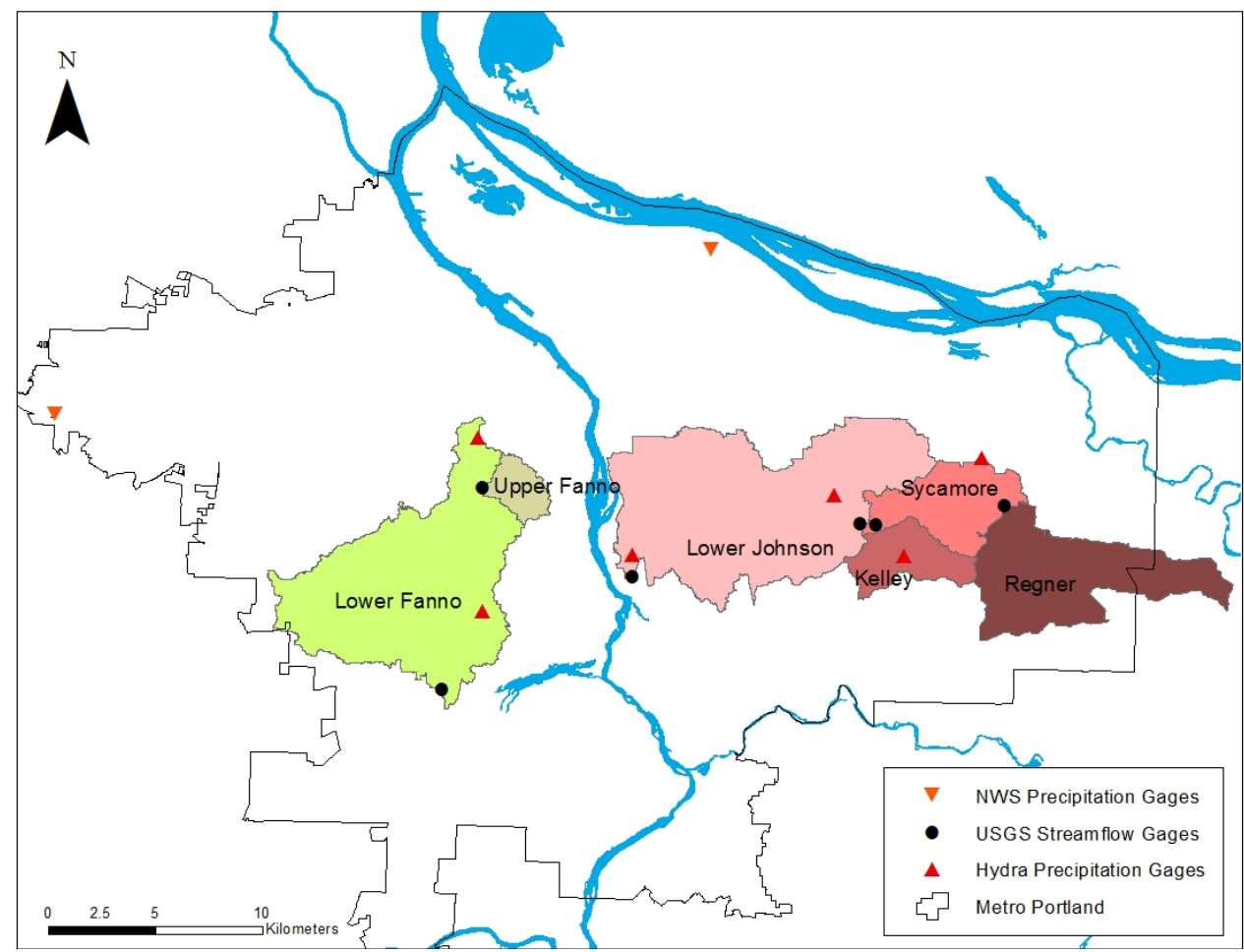

Figure 3. Map of Fanno and Johnson Creek “piped drainage watershed” delineated using both the topology and stormwater sewer network.

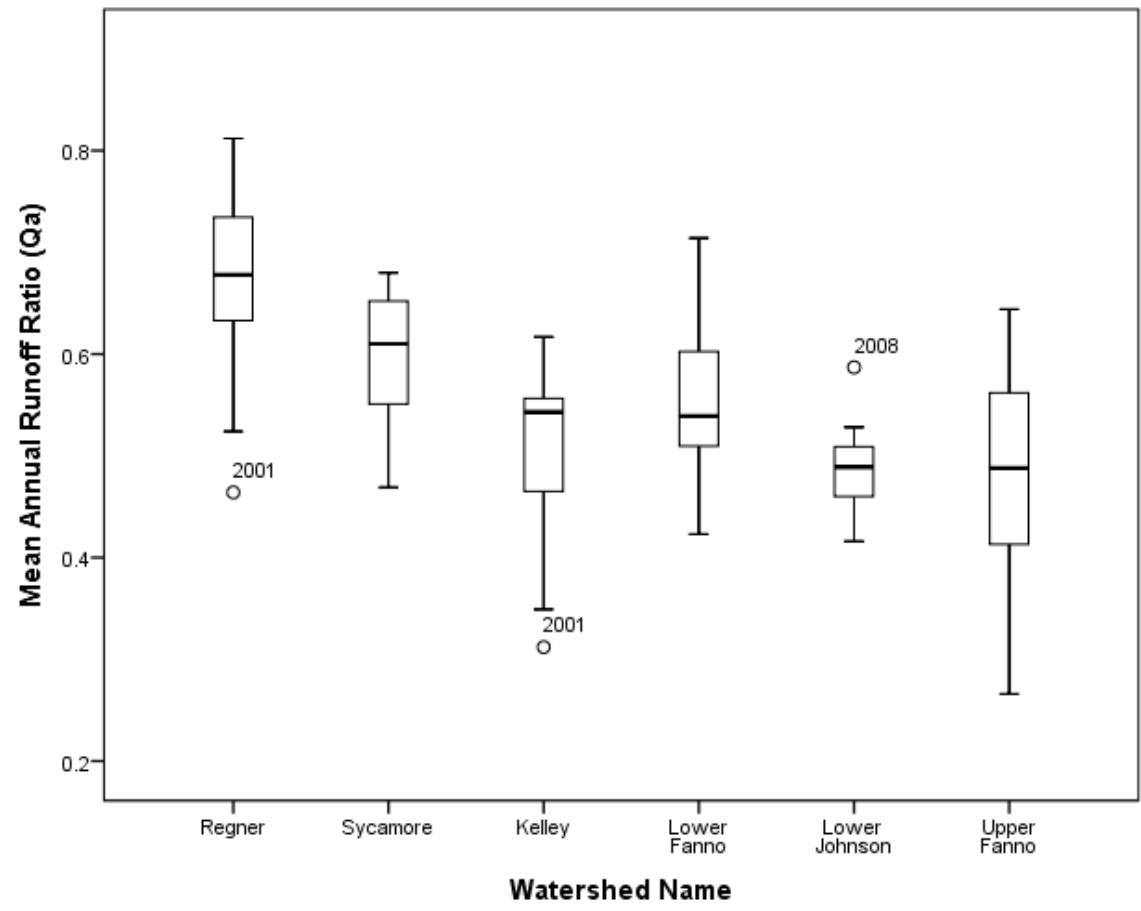

Figure 4. Distribution of mean annual runoff ratios (Q $\left.Q_{a}\right)$ for 2001-2011. 


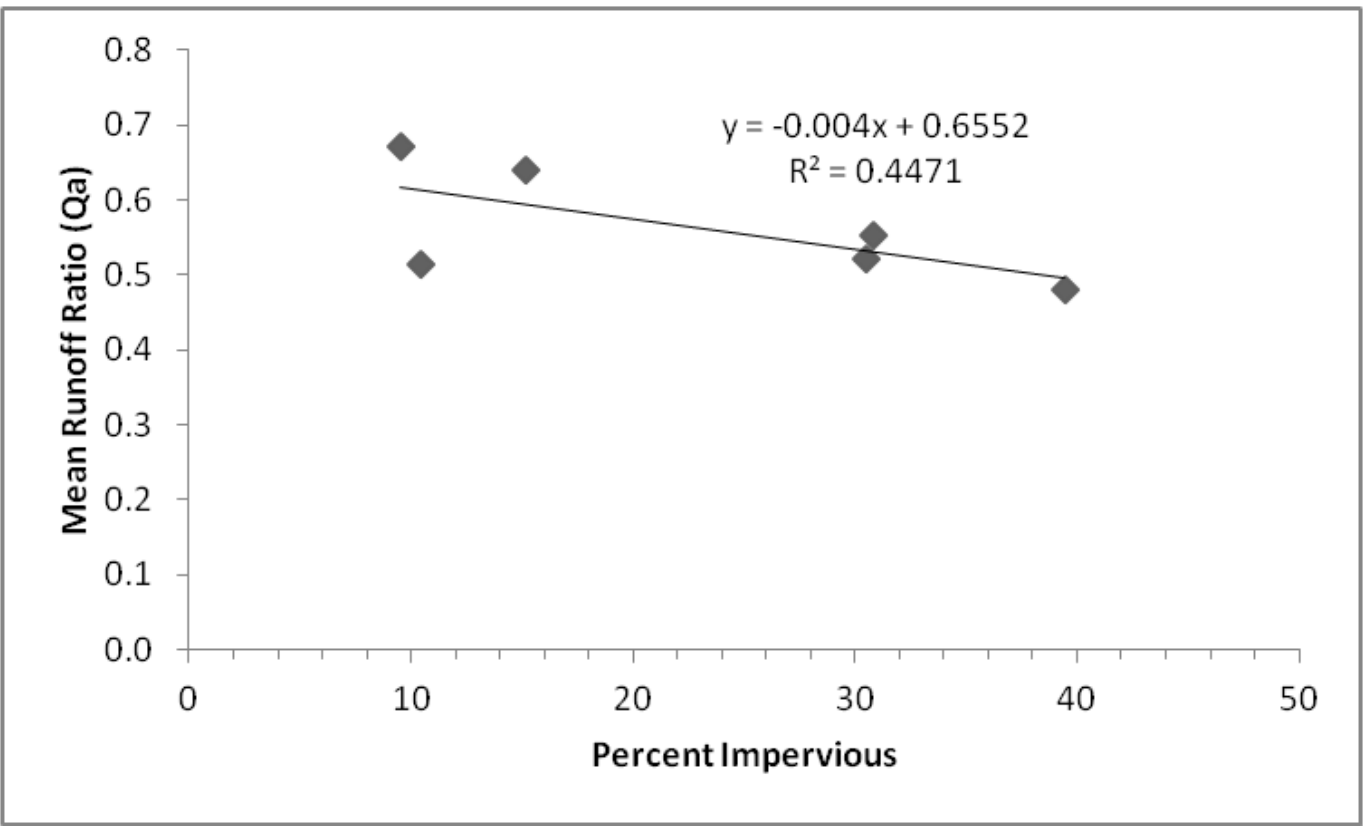

Figure 5. Relationship between mean annual runoff ratio $\left(\mathrm{Q}_{\mathrm{a}}\right)$ and percent impervious.

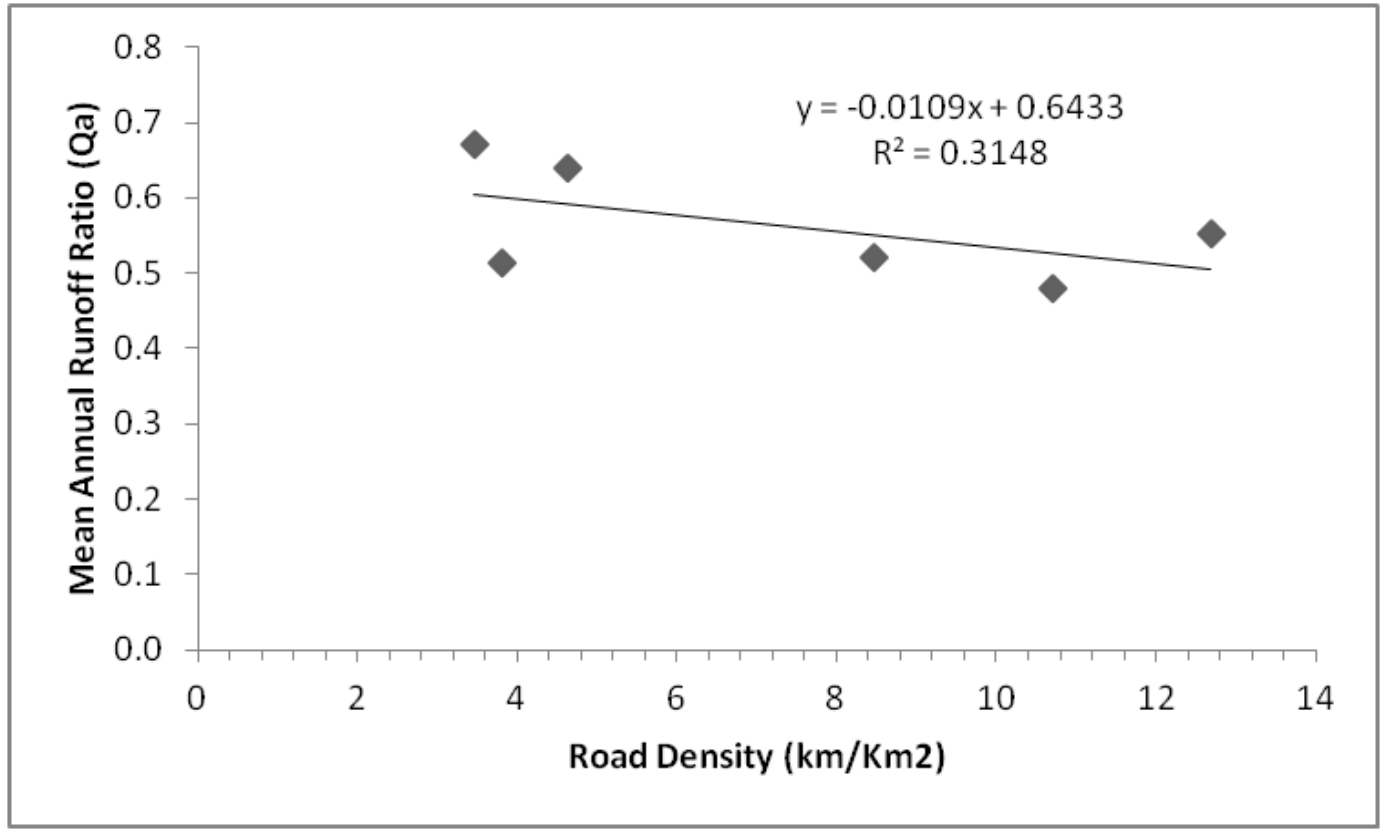

Figure 6. Relationship between mean annual runoff ratio $\left(\mathrm{Q}_{\mathrm{a}}\right)$ and road density. 


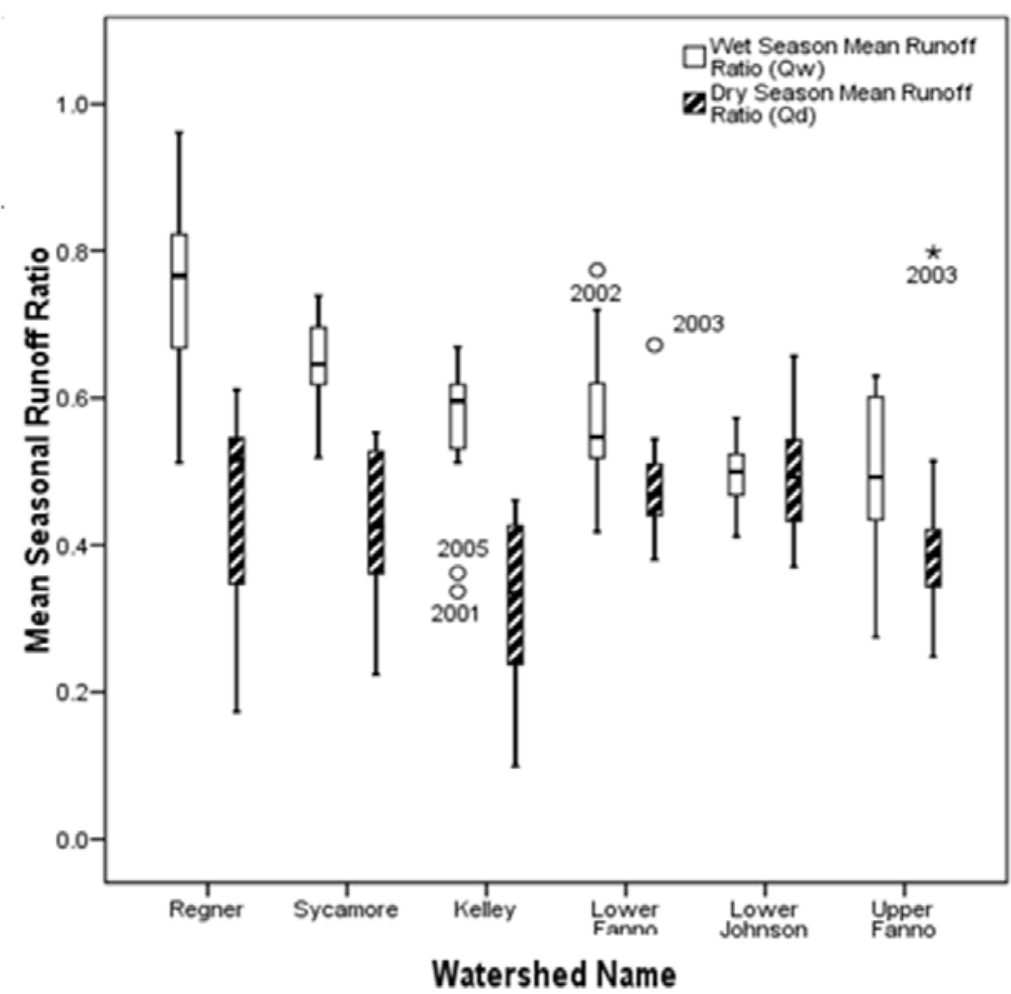

Figure 7. Distribution of mean seasonal runoff ratios $\left(\mathrm{Q}_{\mathrm{w}}\right.$, Wet Season and $\mathrm{Q}_{\mathrm{d}}$, Dry Season) for 2001-2011.

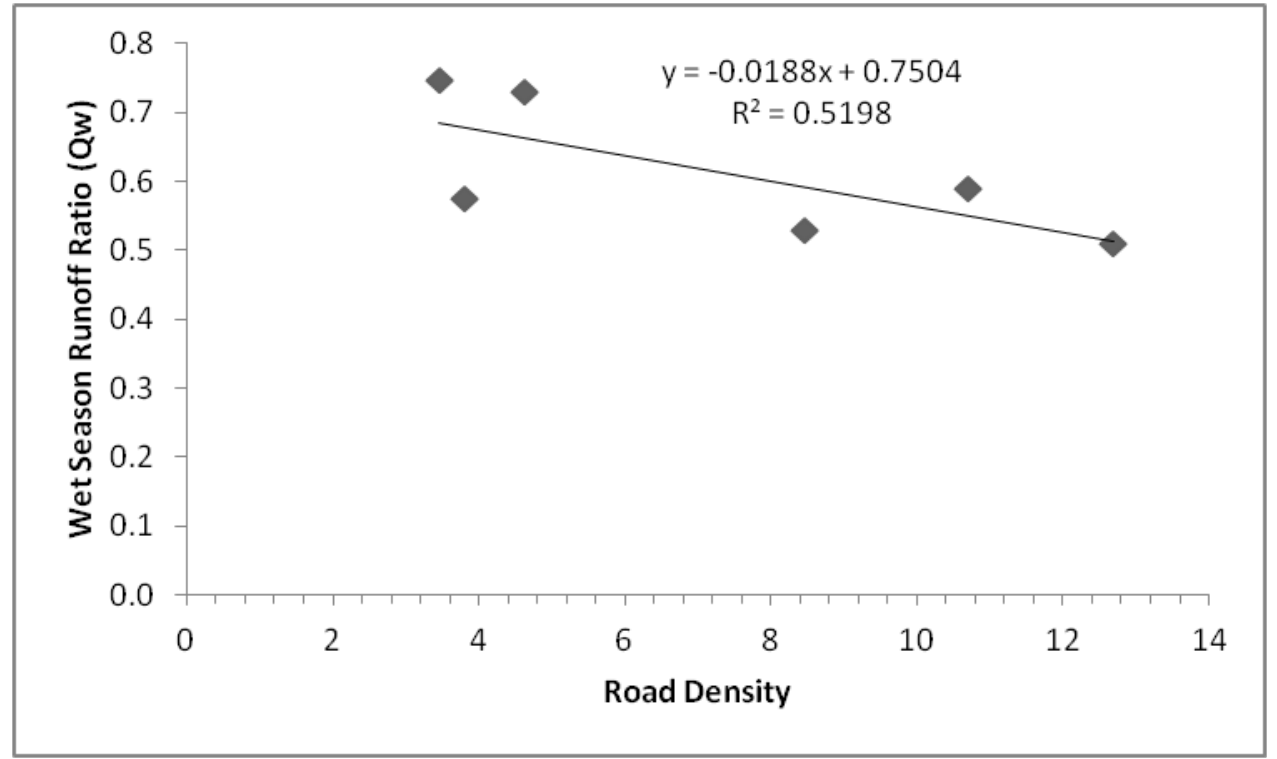

Figure 8. Relationship between road density and the wet season runoff ratio $\left(\mathrm{Q}_{\mathrm{w}}\right)$. 


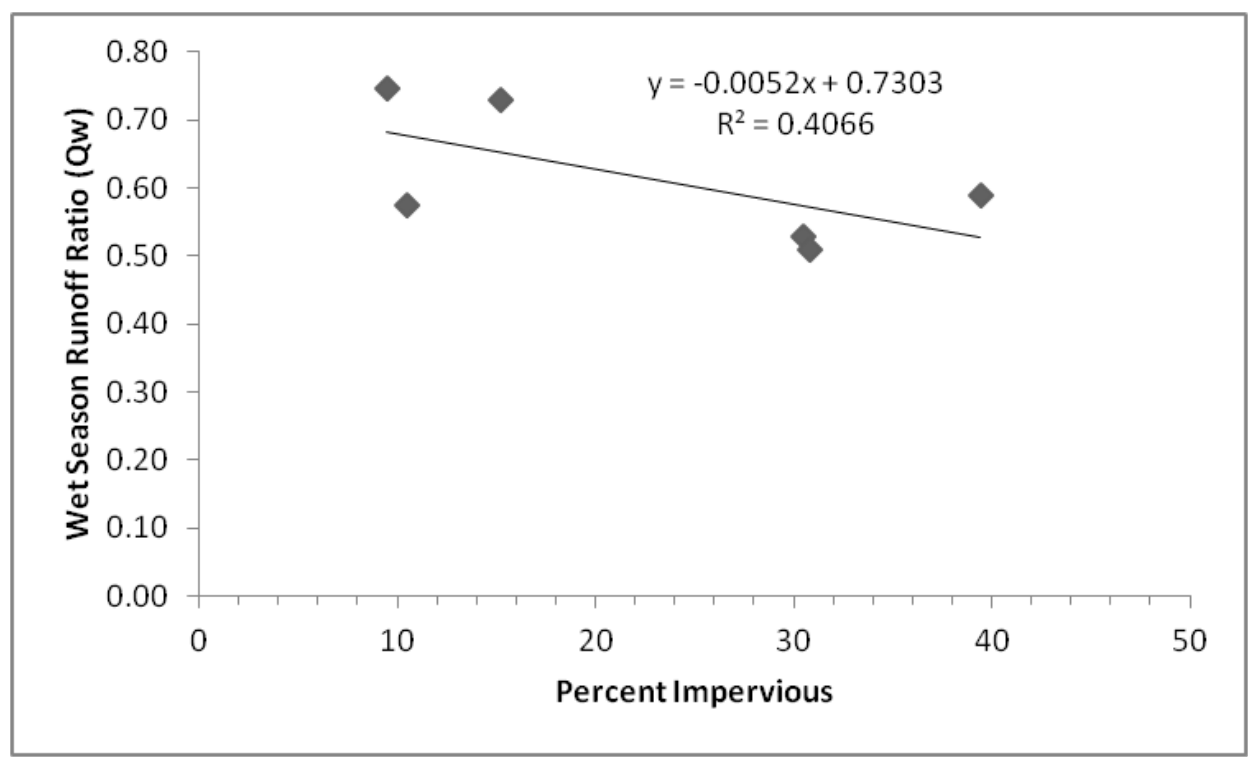

Figure 9. Relationship between percent impervious and the wet season runoff ratio $\left(\mathrm{Q}_{\mathrm{w}}\right)$.

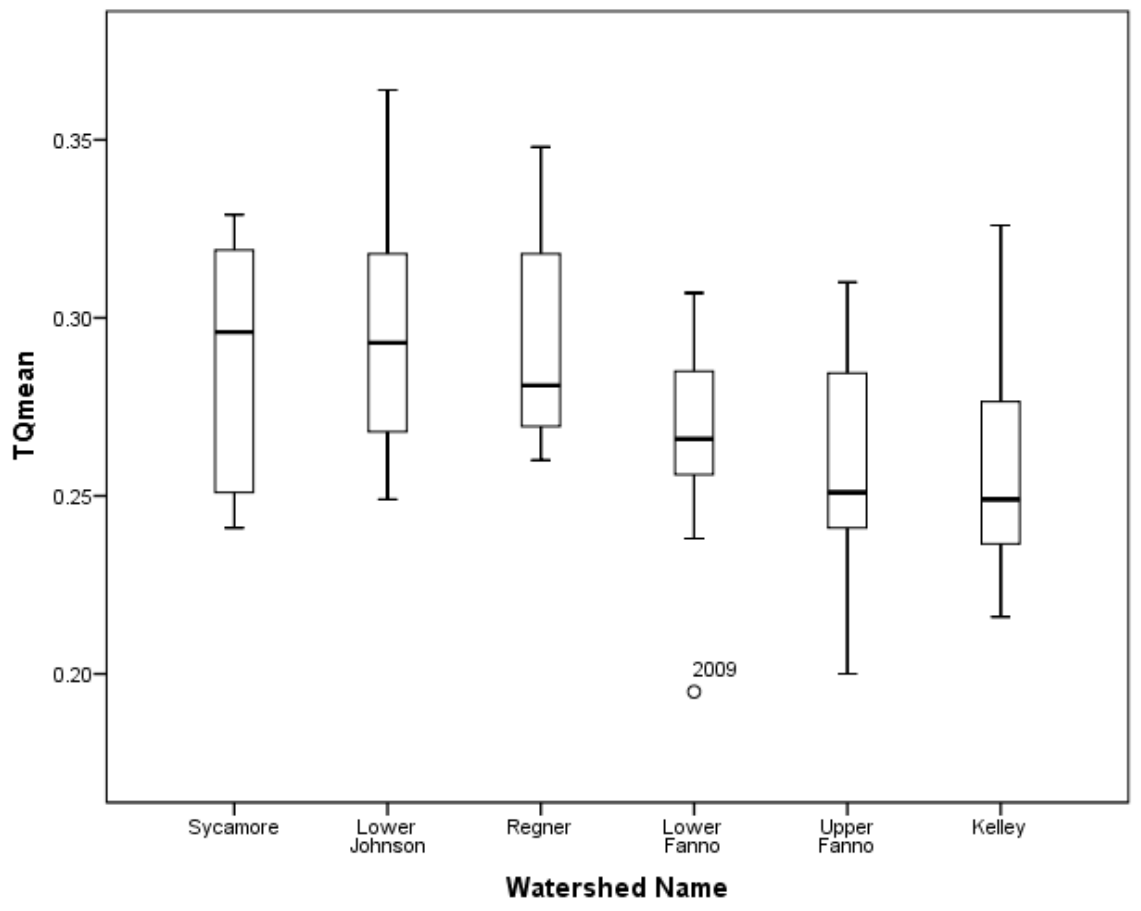

Figure 10. Distribution of fraction of time that daily mean flow exceeds annual mean flow (TQmean) for 2001-2011. 


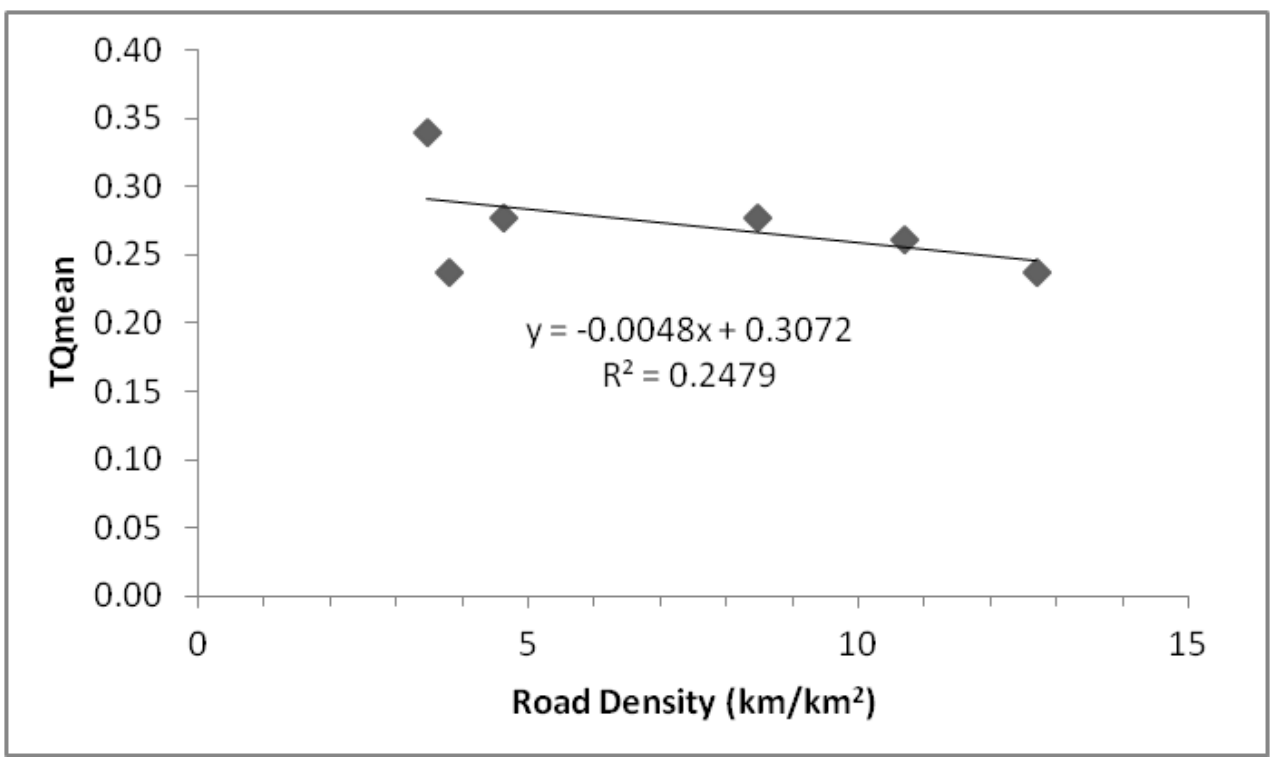

Figure 11. Relationship between TQmean and road density.

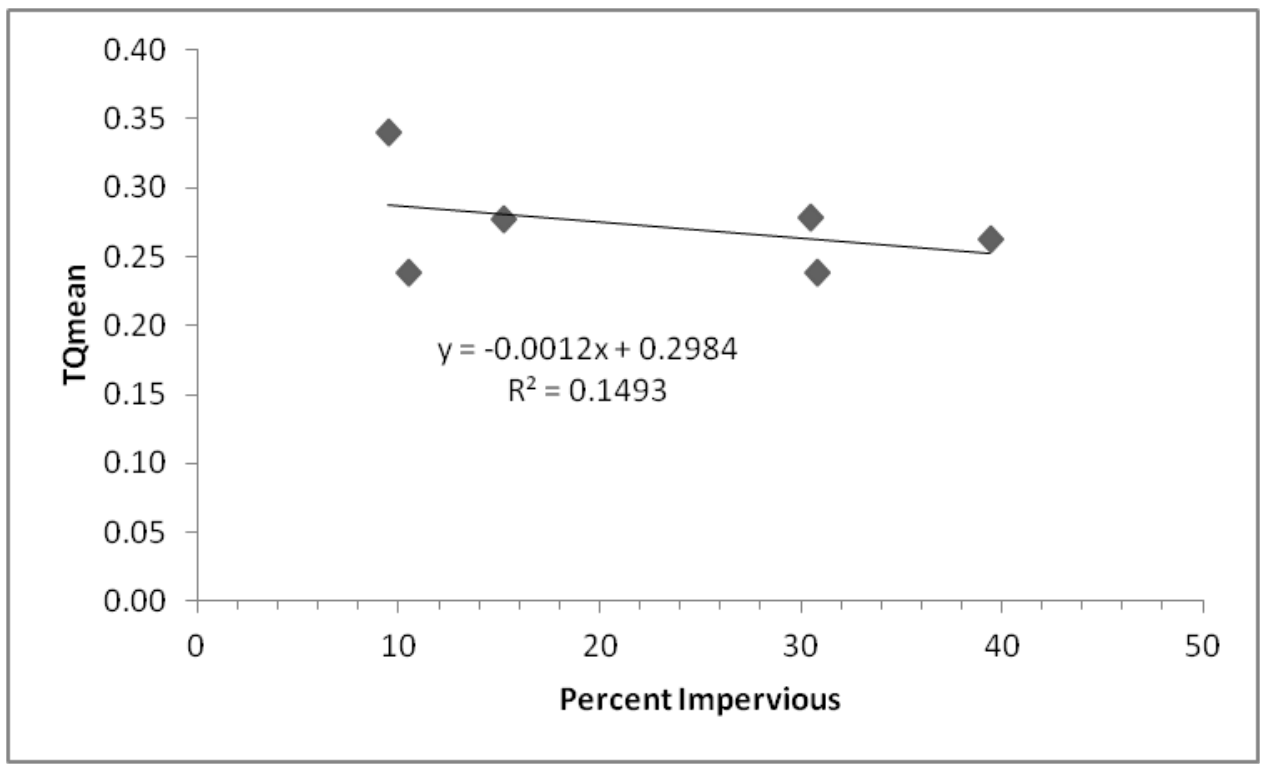

Figure 12. Relationship between TQmean and percent impervious. 


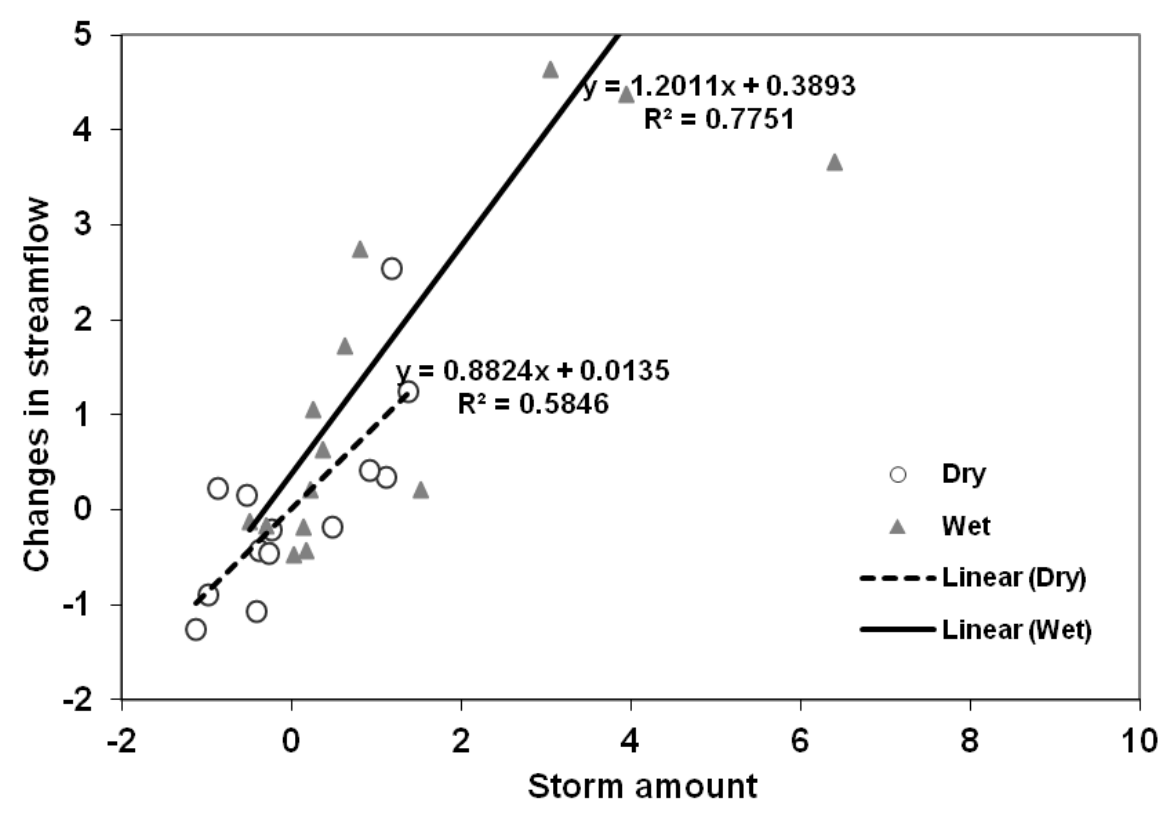

Figure 13. Effects of precipitation on changes in streamflow for Lower Fanno watershed.

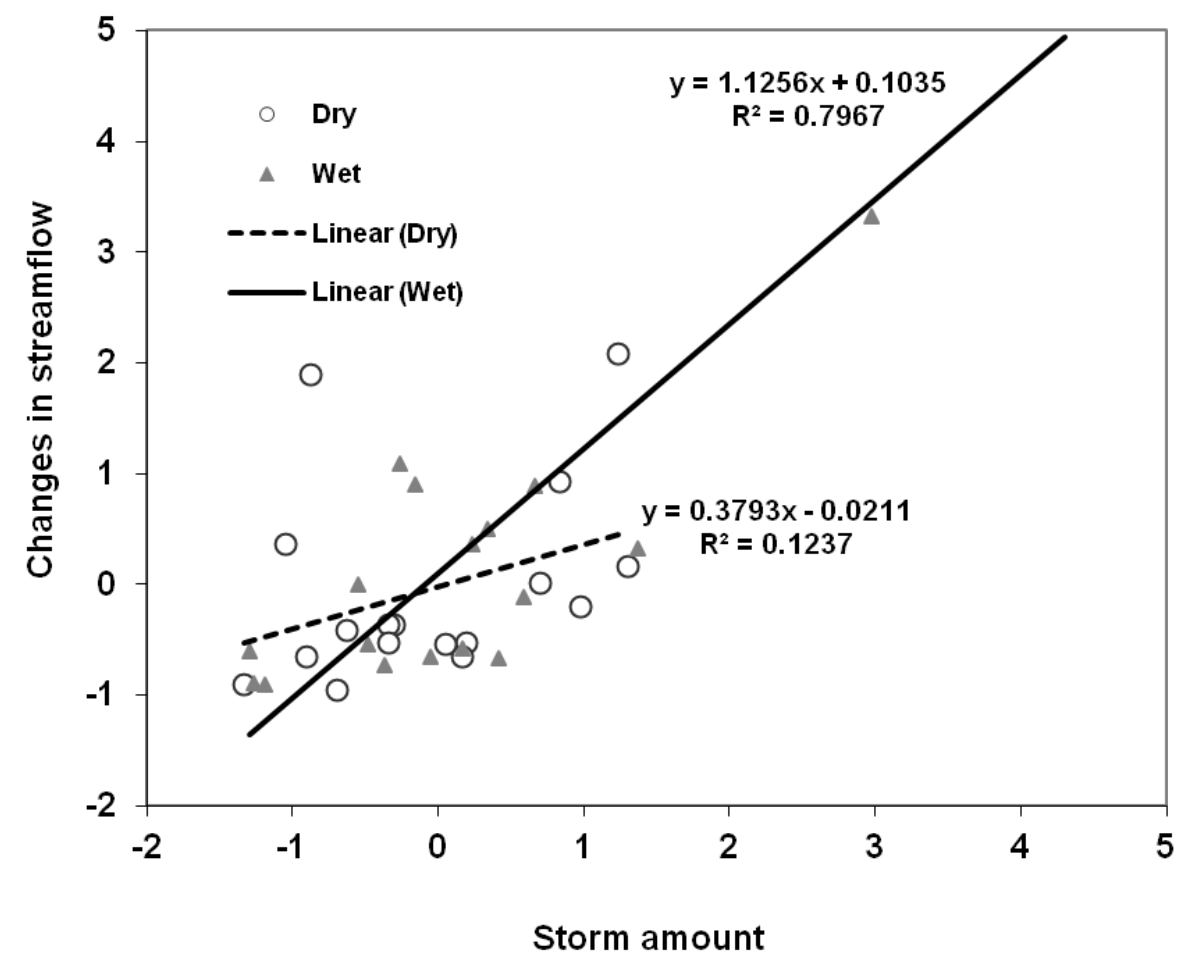

Figure 14. Effects of precipitation on changes in streamflow for the Lower Johnson watershed. 


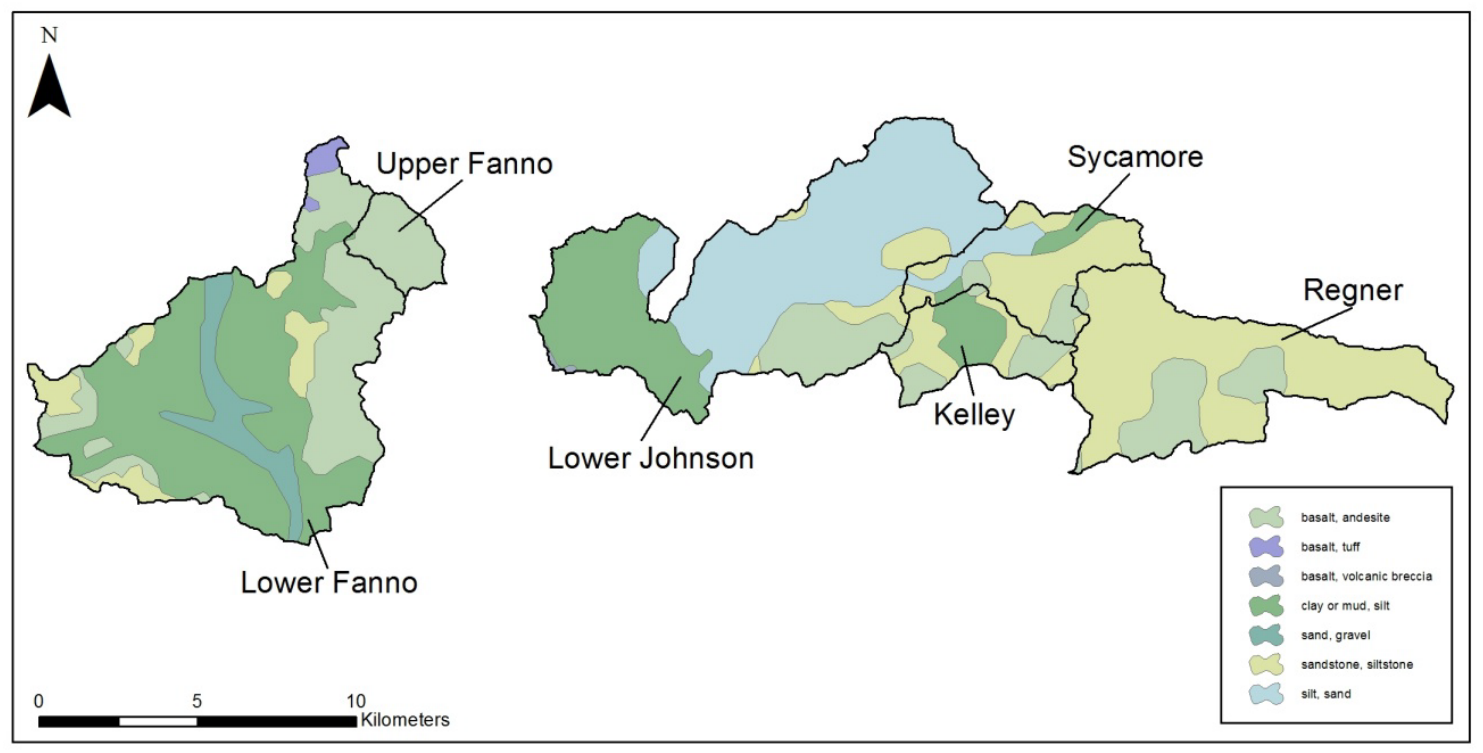

Figure 15.Watershed geology.

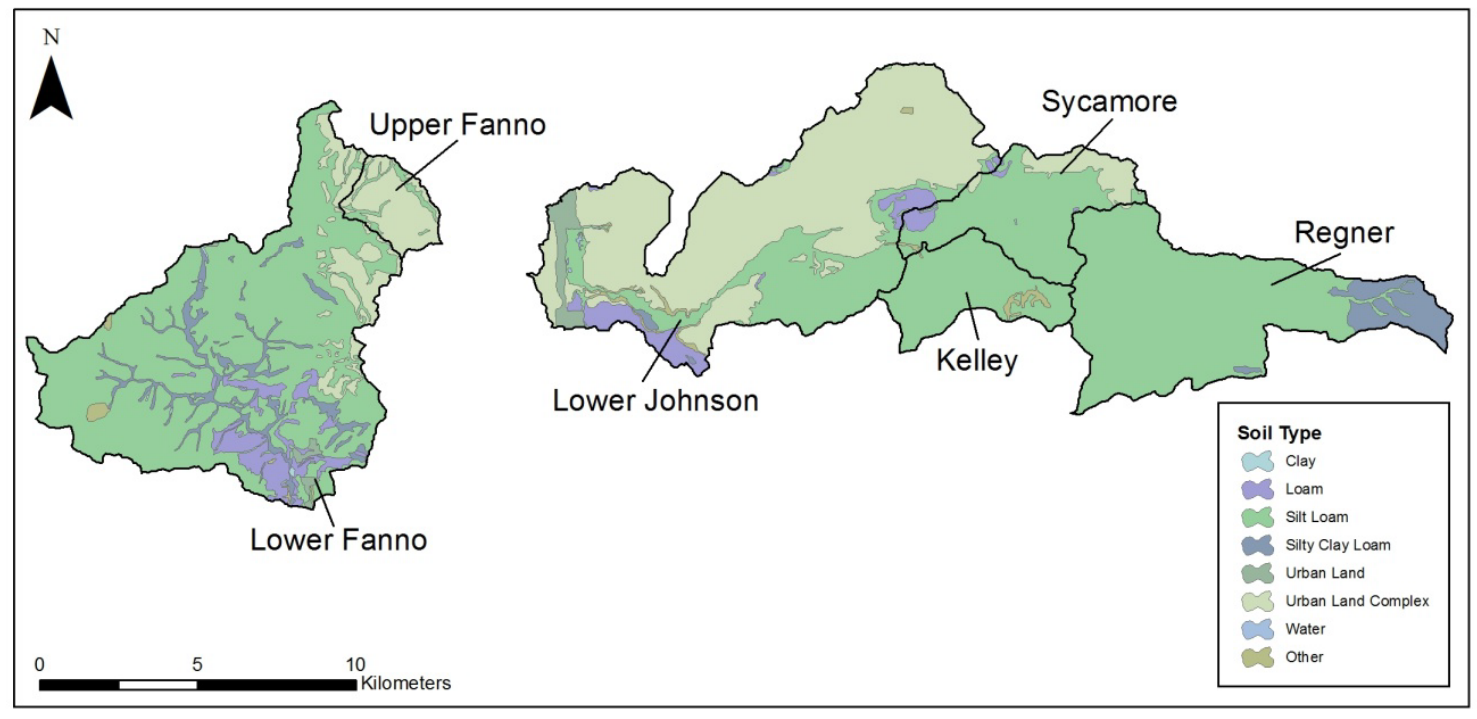

Figure 16. Watershed soil types. 


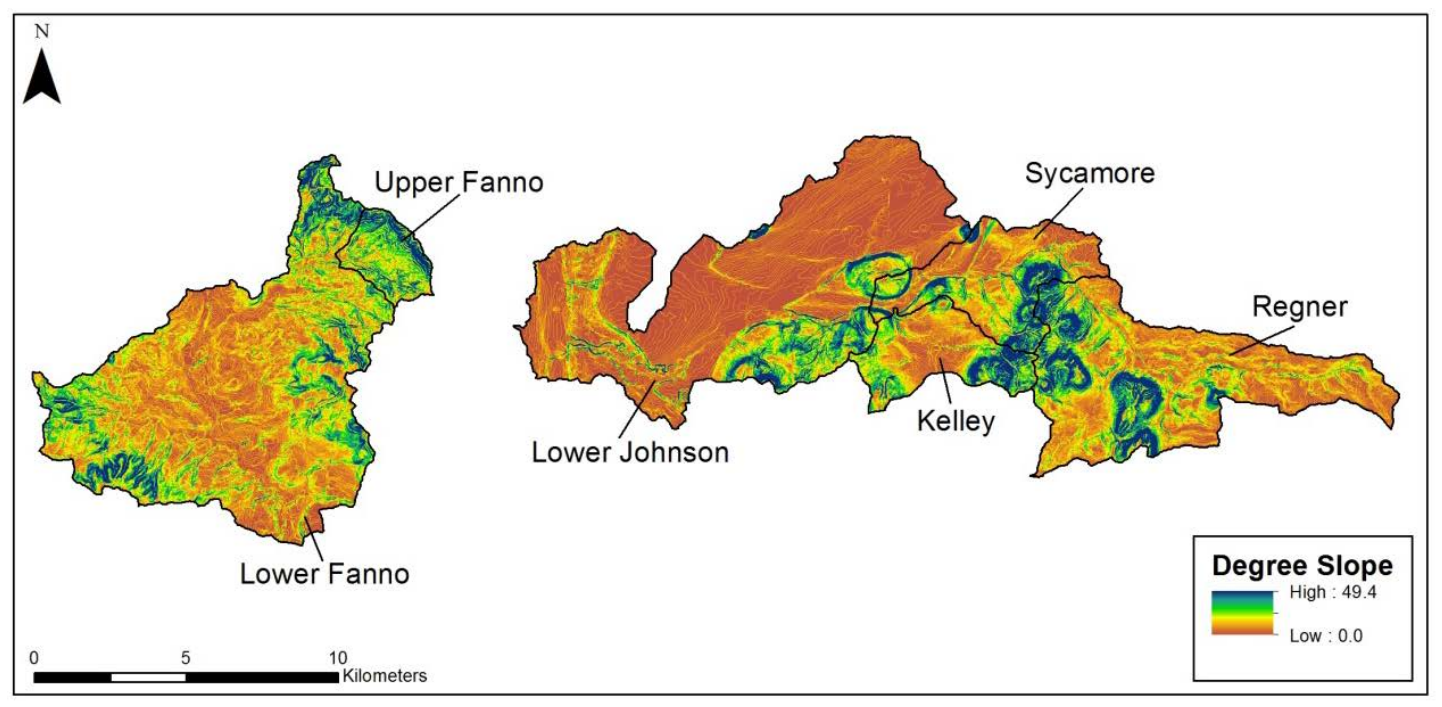

Figure 17. Watershed slope in degrees.

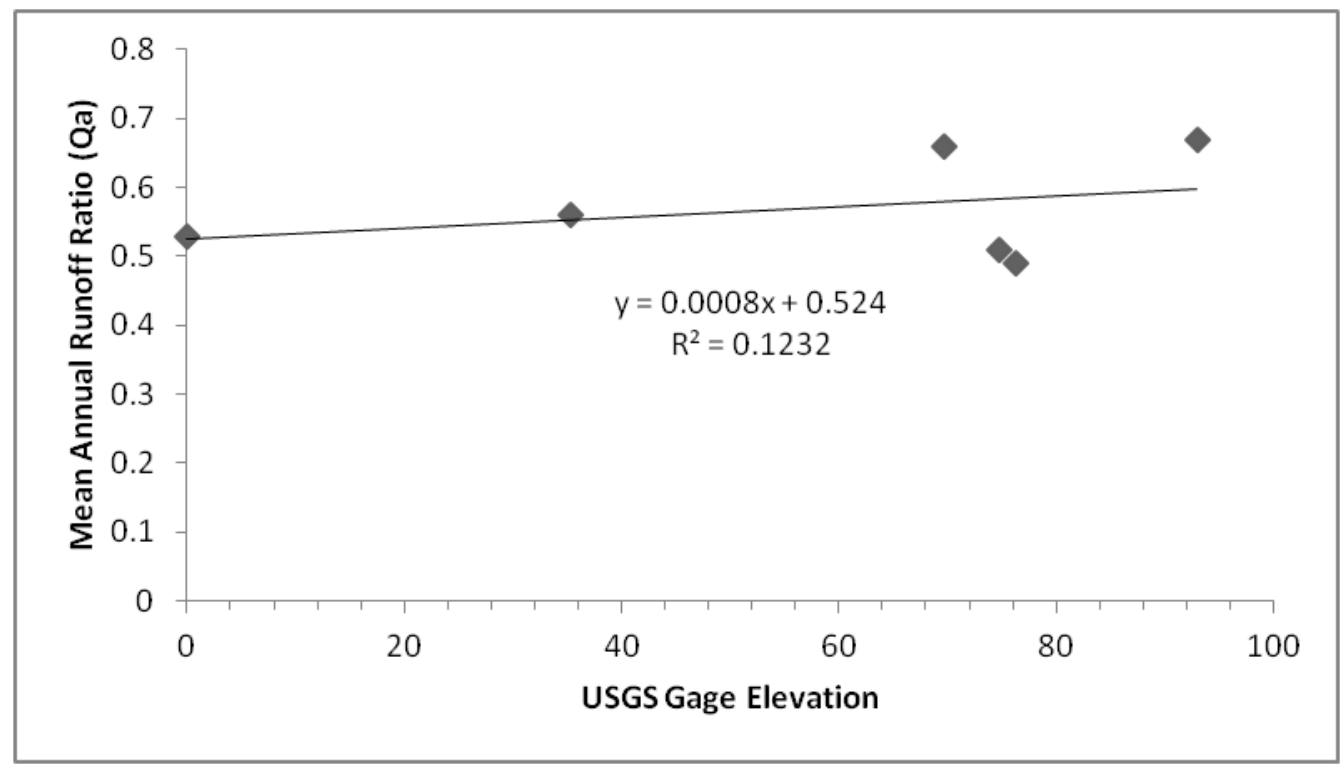

Figure 18. Relationship between USGS gage elevation and mean annual runoff ratio $\left(Q_{a}\right)$. 


\section{References}

Arnold, C. L., and C. J. Gibbons. 1996. Impervious surface coverage: The emergence of a key environmental indicator. Journal of the American Planners Association 62: 243-58.

Bhaduri, B., M. Minner, S. Tatalovich, and J. Harbor. 2001. Long-term hydrologic impact of urbanization: A tale of two models. Journal of Water Resources Planning and Management 27(1): 13-19.

Booth, D. B. 1991. Urbanization and the natural drainage system-impacts, solutions and prognoses. Northwest Environmental Journal 7(1): 93-118.

Booth, D. B., and C. R. Jackson. 1997. Urbanization of aquatic systems: Degradation thresholds, stormwater detention, and the limits of mitigation. Journal of the American Water Resources Association 33(5): 1077-1090.

Cannon, A. J. and P. H. Whitfield. 2001. Modeling transient pH depression in coastal streams of British Columbia using neural networks. Journal of the American Water Resources Association 37(1): 73-89.

Chang, H. 2007. Streamflow characteristics in urbanizing basins in the Portland Metropolitan Area, Oregon, USA. Hydrological Processes 21(2):211-22.

Cianfrani, C. M., W. C. Hession, and D. M. Rizzo. 2006. Watershed imperviousness impacts on stream channel condition in southeastern Pennsylvania. Journal of the American Water Resources Association 42 (4):941-956.

City of Portland, Bureau of Environmental Services. 2012. City of Portland HYDRA Rainfall Network. http://or.water.usgs.gov/non-usgs/bes. Last accessed on March 12, 2012.

City of Portland, Bureau of Environmental Services. 2010. Combined Sewer GIS Data.

Finkenbine, J. K, J. W. Atwater and D. S. Mavinic. 2000. Stream health after urbanization. Journal of the American Water Resources Association 36(5): 11491160 .

Hammer, T. R. 1972. Stream channel enlargement due to urbanization. Water Resources Research 8(6): 1530-1540.

Hardison, E. C., M. A. O'Driscoll, J. P. DeLoatch, R. J. Howard, and M. M. Brinson, 2009. Urban land use, channel incision, and water table decline along coastal plain streams, North Carolina. Journal of the American Water Resources Association 45: 1032-1046.

Hollis, G. E. 1975. The effects of urbanization on floods of different recurrence intervals. Water Resources Research 11: 431-435.

Jones, J. A. A. 1997. Global Hydrology: Processes, Resources and Environmental Management. Prentice Hall: New York. 
Konrad, C. P., D. B. Booth, S. J. Burges. 2005. Effects of urban development in the Puget Lowland, Washington, on interannual streamflow patterns: Consequences for channel form and streambead disturbance. Water Resources Research 4(7): W07009.

Lee, K. K. and D. T. Snyder. 2009. Hydrology of the Johnson Creek Basin, Oregon: U.S. Geological Survey Scientific Investigations Report 2009-5123, 56p.

Leopold, L. B. 1956. Land use and sediment yield. In: Thomas Jr., W.L. (Ed.), Man's Role in Changing the Face of the Earth. University of Chicago Press, Chicago, pp. 639-647.

Leopold, L. B. 1968. Hydrology for Urban Land Planning - A guidebook on the hydrologic effects of urban land use, USGS Circular 554.

Levell, A. P. and H. Chang. 2008. Monitoring the channel process of a stream restoration project in an urbanizing watershed: A case study of Kelley Creek, Oregon, USA. River Research and Applications 24(2): 169-182.

May, C. W., R. R. Horner, J. R. Karr, B. W. Mar and E. B. Welch. 1997. Effects of urbanization on small streams in the Puget Sound lowland ecoregion. Watershed Protection Techniques 2(4): 483-494.

Metro Regional Government. Urban Growth Boundary. 2011. http://library.oregonmetro.gov /files//ugb_hist063011.pdf.

Murphy, Y. M. 2009. Stream channel stability and sensitivity to landscape history and land use changes in Kelley Creek, Portland, Oregon. Master's thesis, Oregon State University.

Paul, M. J., J. L. Meyer. 2001. Streams in the urban landscape. Annual Review of Ecology and Systematics 32: 333-365.

Rose, S., N.E. Peters. 2001. Effects of urbanization on streamflow in the Atlanta area (Georgia, USA): a comparative hydrological approach. Hydrologic Processes 15: 1441-1457.

Roy, A. H., M. C. Freeman, B. J. Freeman, S. J. Wegner, W. E. Ensign, and J. L. Meyer. 2005. Investigating hydrologic alteration as a mechanism of fish assemblage shifts in urbanizing streams. Journal of the American Benthological Society 24(3): 656-678.

Schiff, R. and G. Benoit. 2007. Effects of impervious cover at multiple spatial scales on coastal watershed streams. Journal of the American Water Resources Association 43(3): 712-730.

Schueler, T. 1994. The importance of imperviousness. Watershed Protection Techniques 1(3): 100-111. 
Snyder, D. T. 2008. Estimated depth to ground water and configuration of the water table in Portland, Oregon area: U.S. Geological Survey Scientific Investigations Report 2008-5059.

United Nations Department of Social and Economic Affairs/Population Division. 2008. World Urbanization Prospects: The 2007 Revision. Table A1.

US Census Bureau: State and County Quickfacts.

http://quickfacts.census.gov/qfd/states/4 1/4159000.html. Last accessed 4/10/2012. 